Cornell Law Library

Scholarship@Cornell Law: A Digital Repository

Cornell Law Faculty Publications

Faculty Scholarship

$7-1-2003$

\title{
The Mechanisms of Market Inefficiency: An Introduction to the New Finance
}

Lynn A. Stout

Cornell Law School,1s483@cornell.edu

Follow this and additional works at: http://scholarship.law.cornell.edu/facpub

Part of the Banking and Finance Commons, and the Securities Law Commons

\section{Recommended Citation}

Stout, Lynn A., "The Mechanisms of Market Inefficiency: An Introduction to the New Finance" (2003). Cornell Law Faculty Publications. Paper 450.

http://scholarship.law.cornell.edu/facpub/450

This Article is brought to you for free and open access by the Faculty Scholarship at Scholarship@Cornell Law: A Digital Repository. It has been accepted for inclusion in Cornell Law Faculty Publications by an authorized administrator of Scholarship@Cornell Law: A Digital Repository. For more information, please contact jmp8@cornell.edu. 


\title{
The Mechanisms of Market Inefficiency: An Introduction to the New Finance
}

\author{
Lynn A. Stout*
}

\begin{abstract}
During the 1970s and early 1980s, the Efficient Capital Market Hypothesis (ECMH) became one of the most widely-accepted and influential ideas in finance economics. More recently, however, the idea of market efficiency has fallen into disrepute as a result of market events and growing empirical evidence of inefficiencies. This essay argues that the weaknesses of the efficient market theory are, and were, apparent from a careful inspection of its initial premises, including the presumptions of homogeneous investor expectations, effective arbitrage, and investor rationality. By the same token, a wide range of market phenomena inconsistent with the ECHM can be explained using market models that modify these three assumptions. In illustration, this Article explores three important strands of today's finance literature: (1) the expanding body of work on asset pricing when investors have heterogeneous expectations; (2) recent theoretical and empirical scholarship on how and why arbitrage may move certain types of publicly available information into price more slowly and incompletely than earlier writings suggested; and (3) the exploding literature in "behavioral finance," which examines what happens to prices when market participants do not all share rational expectations. Taken together, these three bodies of work show signs of providing the essential framework on which a new and more powerful working model of securities markets can be built.
\end{abstract}

I. INTRODUCTION 636

II. EFFICIENT MARKETS AND INVESTOR DISAGREEMENT ..........................................639

III. EFFICIENT MARKETS AND THE LIMITS OF ARBITRAGE .......................................6.61

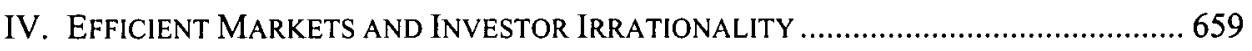

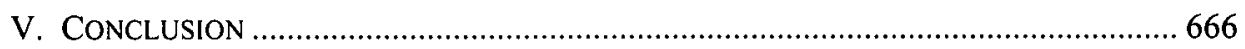

* Professor of Law, UCLA School of Law; Principal Investigator, UCLA-Sloan Foundation Research Program on Business Organizations. An earlier version of this article was presented at the Journal of Corporation Law Symposium on Revisiting the Mechanisms of Market Efficiency, held at The University of Iowa on April 4, 2003. I would like to thank the participants at that conference for their helpful suggestions. I am also especially indebted to Bill Allen, Iman Anabtawi, Steven Bainbridge, Brian Cheffins, Allen Ferrell, Victor Fleischer, Ron Gilson, David Hirshleifer, Peter Huang, Bill Klein, Reinier Kraakman, Jim Lindgren, Lynn LoPucki, and Hillary Sale for their comments and insights on earlier drafts. 


\section{INTRODUCTION}

In 1978, economist Michael Jensen famously pronounced that "there is no other proposition in economics which has more solid empirical evidence supporting it than the Efficient Markets Hypothesis."' Even judged by the evidence available at the time, this claim included a dash of hyperbole. ${ }^{2}$ Yet Jensen's oft-quoted assertion illustrates nicely the extent to which efficient markets theory had, by the 1970 s, captured the imagination of a generation of economists and finance theorists.

Soon after, it captured the imaginations of legal scholars and lawmakers as well. By the mid-1980s, "market efficiency" had become a mantra not only of finance economists, but also of securities scholars, regulators, and even judges and practicing lawyers. As Ronald Gilson and Reinier Kraakman observed in 1984, in their comprehensive law review article on the subject, "[o]f all recent developments in financial economics, the efficient capital markets hypothesis ("ECMH") has achieved the widest acceptance by the legal culture... the ECMH is now the context in which serious discussion of the regulation of financial markets takes place."3

These days, of course, we are not so sure. The idea that securities prices reflect informed estimates of value has always coexisted uneasily with a darker view that sees stock prices as disconnected from economic reality. ${ }^{4}$ Recent events have fed skepticism. The seeds of doubt were first sown widely on October 19, 1987, when the Dow Jones Index of industrial stocks mysteriously lost twenty three percent of its value in a single trading session. ${ }^{5}$ More recently we have seen the appearance and subsequent bursting of a remarkable price bubble in technology stocks that rivals the famous Dutch Tulip Bulb Craze of 1637.6 To some extent, the entire stock market seemed to have been caught in the turbulence: in the Spring of 2000, the Standard \& Poors 500 Index of 500 leading companies topped $1,500 .{ }^{7}$ By October 2002, the S\&P Index was hovering near 775 , a nearly fifty percent dećline in value. ${ }^{8}$

1. Michael C. Jensen, Some Anomalous Evidence Regarding Market Efficiency, 6 J. FIN. ECON. 95, 95 (1978). Ironically, in the same paragraph Jensen cited Thomas Kuhn, see infra text accompanying notes 19 , 167-168, and noted that "widely scattered and as yet incohesive evidence is arising which seems to be inconsistent with the theory." Id.

2. For example, even more extensive empirical evidence supported the economic proposition that when demand increases and supply is fixed, prices rise.

3. Ronald J. Gilson \& Reinier H. Kraakman, The Mechanisms of Market Efficiency, 70 VA. L. REV. 549, 549-50 (1984) (emphasis in original).

4. See, e.g., John M. Keynes, The General Theory of Employment, InTEREST, and Money 156 (1936) (describing the stock market as a "beauty contest" in which investors seek to identify not the best investments but the investments that appear best to others).

5. Lynn A. Stout, The Unimportance of Being Efficient: An Economic Analysis of Stock Market Pricing and Securities Regulation, 87 MICH. L. REV. 613, 617 (1988) [hereinafter Unimportance]

6. See Peter M. Garber, Tulipmania, 97 J. POL. ECON. 535 (1989) (testing for and finding evidence of bubble in seventeenth century tulip market); ANDREI SHLEIFER, INEFFICIENT MARKETS: AN INTRODUCTION TO BEHAVIORAL FINANCE 154 (2000) (describing how, in 1999, the market capitalization of Amazon.com, which was then losing money, was seven times the market capitalization of its two gigantic and highly-profitable "bricks-and-mortar" competitors, Borders and Barnes and Noble).

7. See http://www2.standardandpoors.com/spf/xls/index500_20031009_G5YTOT.xls (table of S\&P 500 values) (last visited Aug. 20, 2003) (showing that on March 24, 2000, S\&P Index was 1,527.47).

8. Id. (showing that on October 9, 2002, S\&P Index was 776.7). 
In the face of such market gyrations, it is difficult for a disinterested observer not to suspect that efficient market theory fails, in some fundamental respect, to capture the reality of securities markets. The thesis of this Article is that we need not have waited several decades to develop this suspicion. Nor need we have suffered through the Crash of 1987 and the 1990 s tech stock bubble to find enlightenment. The weaknesses of efficient market theory were apparent to anyone who cared to look for them within a few years after the theory was first developed and disseminated. ${ }^{9}$

Evidence for this proposition can be found, inter alia, in Gilson and Kraakman's pioneering article The Mechanisms of Market Efficiency. ${ }^{10}$ Ninety-five pages long and containing 247 footnotes, this 1984 law review article is a tour de force that provided as detailed and thorough a summary of the extant literature on market efficiency as anything that had been written at the time by finance economists. ${ }^{11}$ The article offers much more, however, than a comprehensive (if now somewhat dated) literature survey. It also offers a careful and detailed inquiry into the Achilles' heel of efficient market theory-the puzzle of how, exactly, information flows into prices.

Theorists often describe an efficient securities market as one in which prices "fully reflect" all available relevant information. ${ }^{12}$ Yet, as Gilson and Kraakman pointed out, information is costly to obtain, process, and verify. ${ }^{13}$ As a result, it is impossible for every participant in securities markets to actually acquire, understand, and validate all the available information that might be relevant to valuing securities. Efficient market theory nevertheless predicts that "even though information is not immediately and costlessly available to all participants, the market will act as if it were."14

How does this happen? Finance economists often gloss over the problem by simply asserting that if stock prices were to depart from reasonable estimates of value, sharpeyed arbitrageurs would rush into the market to buy or sell, and their trading would move prices back into line. ${ }^{15}$ This belief in the healing powers of arbitrage is so deeply embedded in the literature that it has become a mental habit, rarely subject to conscious scrutiny. Gilson and Kraakman, however, scrutinized it carefully. They put the idea of market efficiency under a microscope, analyzing in impressive detail the question of how, exactly, arbitrage traders armed with information can move prices in a world where other market participants lack that same information. At the end of a sixty-two page discussion

9. By the late 1970 s and early 1980 s, both the theory underlying the ECMH and its empirical soundness had already been called into question by the pioneering work of Edward Miller, Robert Shiller, and others. See, e.g., Edward M. Miller, Risk, Uncertainty, and Divergence of Opinion, 32 J. FIN. 1151 (1977) [hereinafter Risk] (doubting the assumption that investors will make identical estimates of risk and returns); Robert Shiller, $D o$ Stock Prices Move Too Much to Be Justified By Subsequent Changes in Dividends?, 71 AM. ECON. REV. 421 (1981) (refuting the efficient market model as an explanation of stock price volatility).

10. See Gilson \& Kraakman, supra note 3.

11. This may explain why the article has had such influence: a July 14, 2003 search of the LEXIS/NEXIS service's electronic LAWREV database found that the article had been cited over 385 times.

12. Gilson \& Krakman, supra note 3, at 552.

13. Id. at 593-95.

14. Id. at 552 (emphasis added).

15. See, e.g., Richard A. Brealey \& Stewart C. MYers, Principles of Corporate Finance 355-57 (6th ed. 2000) (describing how if arbitrageurs observe a difference between price and value, "they immediately eliminate it by their trading"); Burton G. MALKIEL, A RANDOM WALK DOWN WALL STREET 242-43 (7th ed. 1999) (stating that arbitrage leads to market efficiency). 
(including four full-page diagrams), they concluded that the answer could be found in the complex interaction of at least four imperfect price-moving market mechanisms: "universally informed trading;" "professionally informed trading;" "derivatively informed trading" (including both "trade decoding" and "price decoding"); and "uninfornied trading." 16

Gilson's and Kraakman's analysis of the many and varied ways in which information may be incorporated into securities prices was not only lengthy and intricate - it was, and still is, also quite plausible. And, if it is empirically correct, it offers an important clue to the mystery of why real markets do not behave in the docile fashion theoretical markets do. This is because the market mechanism described by Gilson and Kraakman is anything but a clean, elegant, well-designed machine. Rather, it is a Rube Goldberg apparatus: a jury-rigged contraption full of frail components, weak links, and moving parts, rife with potential for failure.

The Mechanisms of Market Efficiency accordingly offers contemporary observers a valuable roadmap for understanding why markets sometimes work-and why they sometimes do not. This Article follows that roadmap, using The Mechanisms of Market Efficiency as a guide in exploring the oft-questionable assumptions and heuristics that underlie the idea of an efficient market.

Like all theories, the ECMH simplifies a complex reality. Almost as soon as "modern" finance theory (meaning the original and highly-simplified version of efficient market theory developed between 1950 and 1970) first achieved prominence, a new generation of scholars promptly began to revise, extend, and elaborate on it. The discussion below explores some of the more significant and interesting ideas that have come out of this "postmodern" work. In particular, it highlights three important developing strands of thought in finance: (1) the expanding body of work on how asset prices are set when investors have heterogeneous expectations; (2) recent theoretical and empirical scholarship on how and why arbitrage may move some kinds of information into price more slowly and incompletely than earlier writings suggested; and (3) the rapidly-expanding "behavioral finance" literature examining what happens to prices when market participants do not all behave as if they had rational expectations.

As will be seen, even a brief survey of these three bodies of literature suggests a pressing need to reexamine the ECMH's theoretical foundations. It also offers at least two important lessons. The first is that, well before the mounting empirical evidence against market efficiency achieved critical mass, there was good reason to suspect that the relationship between stock prices and economic value was far more indirect than orthodox efficient market theory predicted. This possibility is important not only to academics, but also to lawmakers, businesspeople, and investors. ${ }^{17}$ The notion that

16. Gilson \& Kraakman, supra note 3, at Parts II-III.

17. For example, the idea that stock market prices accurately reflect the value of large corporations provided the foundation for the Securities and Exchange Commission's adoption of the integrated disclosure system, Lynn A. Stout, Are Takeover Premiums Really Premiums? Market Price, Fair Value and Corporate Law, 99 YALE L.J. 1235, 1237 \& n.17, 1293-95 (1990) [hereinafter Takeover Premiums] (discussing integrated disclosure), as well as the passage by a number of state legislatures of "stock market exceptions" to traditional shareholder appraisal rights. Id. at 1286 (discussing stock market exception). Among academics, efficient market theory has led many scholars to try to measure the wisdom of changes in corporate law and corporate charters by looking only to whether such change was accompanied by an increase or decrease in share prices. 
securities prices mirror economic value has had a tremendous influence on the modern business world, shaping basic beliefs about the best way to measure and promote good corporate governance. A salient example can be found in the recent enthusiasm for "incentivizing" corporate officers and directors by compensating them primarily, or even solely, through options and stock-based compensation schemes. ${ }^{18}$ If market prices do not closely reflect actual expected risks and returns, this single-minded focus on share price is a recipe for mismanagement.

The second important lesson to be learned from the new finance literature, however, is that even if the relationship between stock price and value is far more complex than the orthodox ECMH predicts, this does not mean that it lies beyond our understanding. There is no need to throw up our hands and abandon any attempt to analyze the market. To the contrary, if we are willing to modify some of the assumptions that underlie orthodox efficient market theory, and allow the analysis to get a bit more complicated, we may be able to develop a much better working model of how, exactly, securities markets set prices. To describe the current state of the field of finance in Kuhnian terms, the old paradigm of an efficient market is crumbling. ${ }^{19}$ However, the outlines of a new paradigm are dimly visible in the resulting cloud of intellectual dust.

\section{EFFICIENT MARKETS AND INVESTOR DISAGREEMENT}

To understand the limits of orthodox efficient market theory, it is necessary to first inquire into what, exactly, commentators mean when they describe a market as "efficient." According to the most common definition, a market is "efficient" when prices always fully reflect available information. ${ }^{20}$ As has been observed, however, this shorthand description does not provide much guidance without a more detailed understanding of what the phrase "fully reflect" means. ${ }^{21}$

At least two different understandings of "fully reflect" appear frequently in the finance literature (often in the same article, and sometimes used interchangeably). The first understanding focuses on whether information can be used to extract trading profits. As Gilson and Kraakman put it, "[t] $]$ he common definition of market efficiency ... is really a shorthand for the empirical claim that 'available information' does not support profitable trading strategies or arbitrage opportunities." 22 Thus the market is efficient

See infra text accompanying notes $71-72$ (discussing event studies).

18. See, e.g., Gerald A. Feltham \& Martin G.H. Wu, Incentive Efficiency of Stock Versus Options, 6 REV. ACCT. STUD. 77 (2001) ("a firm's stock price is often used as a performance measure in determining management compensation because incentive devices based on the stock price directly align management's interests with the equity-holders'..."); James E. Heard, Executive Compensation: Perspective of the Institutional Investor, 63 U. CIN. L. REV. 749 (1995) (arguing that stock-based incentive compensation plans align shareholder and manager interests)

19. Thomas S. KuHN, The Structure of SCIEnTIFIC Revolutions (2d. ed., 1970).

20. Gilson \& Kraakman, supra note 3, at 554. See, e.g., Eugene F. Fama, Efficient Capital Markets: A Review of Theory and Empirical Work, 25 J. FiN. 383 (1970) (stating "a market in which prices always 'fully reflect' available information is called 'efficient"').

21. See, e.g., Fama, supra note 20, at 384; Gilson \& Kraakman, supra note 3, at 557; Jensen, supra note 1, at 97 .

22. Gilson \& Kraakman, supra note 3, at 555. See, e.g., Jensen, supra note 1, at 96 ("A market is efficient with respect to [an] information set ... if it is impossible to make economic profits by trading on the basis of [that] information set ...."). 
with respect to a piece of information if a trader who becomes aware of the information cannot make money by trading on it. (An example would be an investor who decides to sell a stock upon the public announcement of a decline in corporate earnings, who finds that by the time she calls her broker, the price has already dropped.) One of the most salient implications of this view of market efficiency-sometimes dubbed informational efficiency $y^{23}$-is that in an efficient market, traders cannot profit from trading on publicly available information in a way that allows them to "beat the market." 24

The concept of informational efficiency accordingly can be understood as a prediction or implication about the speed with which prices respond to information. ${ }^{25}$ Yet the concept of informational efficiency, alone, does not necessarily imply that market prices are going to respond to information correctly, or even that prices are going to respond at all. This argument is explored in greater detail later. ${ }^{26}$ For present purposes it suffices to note that the connection often drawn between the rapid absorption of information into price, and market prices that accurately reflect economic value, reflects a second common understanding of market efficiency sometimes called fundamental value efficiency. ${ }^{27}$

Markets are efficient in the fundamental value sense if stock prices respond to available information not only quickly but accurately, so that market prices mirror the best possible estimates, in light of all available information, of the actual economic values of securities in terms of their expected risks and returns. (Gilson and Kraakman seem to be thinking of fundamental value efficiency when they suggest that an efficient market will set prices identical to the equilibria that would be set if everyone were "fully informed," including being optimally informed about future cash flows). ${ }^{28}$ Despite the

23. See, e.g., Sanford J. Grossman \& Joseph E. Stiglitz, On the Impossibility of Informationally Efficient Markets, 70 AM. ECON. REV. 393, 395 (1980) (describing a market as "informationally efficient" when "prices are such that all arbitrage profits are eliminated"); Lynn A. Stout, Are Stock Markets Costly Casinos? Disagreement, Market Failure, and Securities Regulation, 81 VA. L. REv. 611, 646-47 (1995) (distinguishing informational from fundamental value efficiency) [hereinafter Casinos]; William K.S. Wang, Some Arguments that the Stock Market is Not Efficient, 19 U.C. DAVIS L. REV. 341, 344-49 (1986) (same); see also NichOLAS BARBERIS \& RICHARD THALER, A SURVEY OF BEHAVIORAL FINANCE 4 (2002), available at http://ssrn.com/abstract $=327880$ (last visited Aug. 20,2003) (distinguishing between the claim that there are no arbitrage opportunities, and the claim that stock prices accurately reflect fundamental value, noting that a market may conform to the first claim without conforming to the latter).

24. Conventional finance recognizes that this cannot be absolutely true, or no one would have incentive to trade on information in a way that leads to the incorporation of that information into prices. Thus it has been suggested that efficient markets have an "efficient degree of inefficiency," meaning enough profit opportunities exist to support a small professional class of arbitrageurs. The average investor, however, cannot earn profits from trading on public information in such a market. See generally Grossman \& Stiglitz, supra note 23.

Conventional finance also recognizes that there is some uncertainty about when, exactly, information becomes "available." It had become tradition to adopt Fama's distinction between a "weakly" efficient market in which prices reflect all past price patterns, a "semistrong" market in which prices reflect all other publicly accessible information, and a "strong" efficient market in which prices reflect not only all public information, but also private, proprietary information available only to corporate directors, employees, and other "insiders." See Fama, supra note 20, at 388 (developing distinction).

25. See Gilson \& Kraakman, supra note 3, at 560.

26. See infra text accompanying note 68 .

27. See, e.g., Stout, Casinos, supra note 23, at 647 (discussing fundamental value efficiency); William K.S. Wang, supra note $23,344-49$ (same).

28. See Gilson \& Kraakman, supra note 3, at 560-61 \& n.4l (discussing how the information that is 
fact that informational efficiency and fundamental value efficiency are distinct concepts, the two can be, and often are, made to go hand-in-hand, with fundamental value efficiency flowing naturally from informational efficiency. To accomplish this, however, requires a theory of how market participants use information to estimate values and set prices. The most widely-employed of these theories-relied upon, inter alia, by Gilson and Kraakman-is the Capital Asset Pricing Model (CAPM). ${ }^{29}$

Although the mathematics underlying the CAPM are somewhat forbidding, the intuition is straightforward. The CAPM posits that investors value securities according to only two criteria: expected return, and expected nondiversifiable (or market) risk. ${ }^{30}$ Because investors are assumed to like returns but dislike risk, there is an inverse relationship between the two. Moreover, this relationship is linear. As the market risk associated with a particular security increases, the expected return investors demand before they are willing to hold that security increases in direct proportion.

When the CAPM is combined with the ECMH, the two theories produce a joint prediction that, in an informationally efficient market, prices will also be fundamental value efficient. That is, securities with identical estimated levels of market risk will trade at prices that imply identical expected rates of return. How does this prediction follow from the two theories? As noted earlier, commentators sometimes assume that arbitrage provides the answer: that if prices were not fundamental value efficient, it would be available information that some securities were bargains relative to others, and traders would quickly recognize this and trade the difference away. ${ }^{31}$ More careful inquiry reveals this is not the correct explanation. Combining the ECMH with the CAPM produces a prediction of fundamental value efficiency through a different and more troubling analytical path-by tautology.

One of the most remarkable (yet remarkably unremarked-upon) ${ }^{32}$ characteristics of the classic CAPM is that the pioneering theorists who developed it began by expressly assuming that all investors share homogenous expectations regarding the likely future

reflected in price in an efficient market includes not only information about past events but also optimal forecasts of future cash flows). See also Fama, supra note 20, at 384 (discussing how prices fully reflect information if they mirror expected returns); BREALEY \& MYERS, supra note 15, at 375 (suggesting that one can trust efficient market prices to reflect unbiased estimates of value).

29. Gilson \& Kraakman, supra note 3, at n.41 (discussing CAPM); see generally BREALEY \& MYERS, supra note 15, at 195-203 (same); MALKIEL, supra note 15, at 224-29 (same).

30. Finance theorists refer to probabilistic variations in returns as risk. Some sources of risk are unique to particular corporations. Thus, airline company stocks are likely to fall when fuel prices are high, while the prices of oil firms rise. Because diversified investors can eliminate such "firm-specific" risk by simply holding a diversified portfolio, they do not demand additional returns in order to hold stocks that have a high firmspecific risk. However, some sources of risk reflect macroeconomic factors likely to affect all stocks the same way. Diversification cannot eliminate such "market" risk. Therefore, investors demand a higher return before they are interested in buying stock of a company with a high degree of market risk. See generally BREALEY \& MYERS, supra note 15, at 153-73 (discussing risk); MALKIEL, supra note 15, at 200-224 (same).

31. See supra text accompanying note 15 (discussing arbitrage assumption).

32. See, e.g., BREALEY \& MYERS, supra note 15, at 195-203 (discussing CAPM without mention of homogeneous expectations assumption). Interestingly, Gilson \& Kraakman expressly reference the homogeneous expectations assumption. This suggests that the implausibility of CAPM's homogeneous expectations assumption was recognized when the model first arrived on the scene. Over time, however, CAPM became so well accepted that even sophisticated observers rarely bothered to reexamine, much less question, its premises. 
returns and risks associated with particular securities. ${ }^{33}$ In other words, they assumed that all investors agree. It should be apparent to anyone with experience in the business world or exposure to the business media that people do not, in fact, share identical views of the intrinsic economic worth of particular securities. If they did, it is hard to explain why most mutual funds are actively managed, or why U.S. firms often see 100 percent or more of their shares change hands annually. ${ }^{34}$

Despite its empirical unsoundness, the simplifying assumption of homogeneous investor opinion is harmless when CAPM is used for its original, intended purpose of describing the individual investor's attitude towards risk and return. There is danger, however, when CAPM is used either expressly or impliedly to argue that the market prices securities accurately in terms of their expected risks and returns. At this point, the reasoning becomes circular. If investors make identical estimates of securities' future risks and returns, it is inevitable that the market should mirror this "best" estimate, because there is only one estimate-the estimate of the homogenous investor.

This observation sets the stage for introducing one of the most intriguing and potentially powerful strains of the new finance-the expanding literature on how asset prices may be set in a world where investors hold disagreeing opinions. To understand this literature, it is useful to start with the conventional CAPM and ask the question, what happens to the CAPM if we assume that investors disagree about the likely future risks and returns of stocks? An interesting quirk of the original CAPM model quickly emerges: when we modify CAPM to account for heterogeneous investor opinion, while still assuming perfect markets, price-moving arbitrage of the sort assumed by many commentators (and explored in detail by Gilson and Kraakman) becomes impossible. Indeed, market equilibrium becomes impossible.

To see why this is so, imagine a highly simplified market with only one security, stock issued by Widget Corp. at $\$ 100$ per share. Assume also that there are only two

33. See John Lintner, The Valuation of Risk Assets and the Selection of Risky Investments in Stock Portfolios and Capital Budgets, 47 REV. ECON. \& STAT. 13, 14 (1965) (relating risk and uncertainty with the selection process under "idealized conditions"); William F. Sharpe, Capital Asset Prices: A Theory of Market Equilibrium Under Conditions of Risk, 19 J. FIN. 425, 427 (1964) (assuming that the investor will view outcome in "probabilistic terms").

Although Sharpe and Lintner are often credited with developing the CAPM and eventually won the Nobel Prize in economics for their work, their manuscripts on the subject were pre-dated by the circulation of a paper by a third individual, Jack Treynor. Treynor is increasingly being credited with first developing the CAPM, although his article on the subject was not published (and the Nobel Prize committee has yet to call him). See BREALEY \& MYERS, supra note 15, at 195 n.10 (discussing Treynor's role); Craig French, The Treynor Capital Asset Pricing Model, 1 J. INV. MGMT. 60 (2003) (arguing that history should attribute first development of CAPM to Treynor).

Interestingly, Sharpe and Lintner both subsequently published work on asset pricing under conditions of investor heterogeneity. See John Lintner, The Aggregation of Investor's Diverse Judgments and Preferences in Purely Competitive Security Markets, 4 J. Fin. \& QuANTATIVE ANALYsis 347 (1969) [hereinafter Diverse Judgments]; WILLIAM F. SHARPE, PORTFOLIO THEORY AND CAPITAL MARKETS 104-13 (1970) (chapter entitled "Disagreement") [hereinafter Disagreement]. Treynor's subsequent work also considers the role of heterogeneous expectations in markets. See, e.g., Jack Treynor, Bulls, Bears and Market Bubbles, 54 FIN. ANALYSTS J. 69 (1998).

34. See, e.g., Stout, Casinos, supra note 23, at 621 (noting that in 1992, shares in NASDAQ firms experienced $160 \%$ turnover); NYSE Factbook Online, Annual Reported Volume, Shares Listed, Turnover Rate, Reported Trades, available at http://www.nysedata.com/factbookviewer_edition.asp?mode=table\&key=63\& category $=4$ (last visited Aug. 20, 2003) (showing 105\% turnover in equity shares in 2002). 
investors: Bull, who thinks Widget stock is worth $\$ 101$, and Bear, who thinks it worth $\$ 99$. In a perfect market with no risk aversion, wealth limitations, transactions costs, or restrictions on short selling, even this very modest disagreement makes an equilibrium price impossible. This is because Bull will see the chance to buy "undervalued" Widget stock as a money machine, and will buy and buy, until the supply of Widget stock is exhausted. The supply will never be exhausted, however, because Bear simultaneously sees a chance to make money by selling Widget stock short, and will borrow it, and borrow still more of it (presumably from Bull), to sell it short (again, presumably to Bull). ${ }^{35}$ The end result is that Bull and Bear place infinite bets against each other, and no equilibrium emerges.

To achieve an equilibrium price under conditions of disagreement, it is necessary to assume some form of market imperfection. This inevitably complicates the analysis, which may help to explain why the homogeneous-expectations CAPM is what is taught in most introductory finance texts. ${ }^{36}$ Yet, those willing to expend the extra intellectual effort associated with exploring the heterogeneous expectations asset pricing literature will be amply rewarded. With just a few plausible modifications, we can build an alternative asset pricing model that explains many of the puzzling characteristics of modern securities markets that cannot be explained under the conventional CAPM. ${ }^{37}$

In illustration, consider a relatively simple variant of the CAPM that has attracted a good deal of attention from the latest generation of finance theorists. This variant was first explored in depth in a 1977 paper by Edward Miller. ${ }^{38}$ In that paper (recently described in the Wall Street Journal as "famous"), ${ }^{39}$ Miller examined how market prices are set in a market given three realistic assumptions: (1) investor disagreement; (2) limits on short selling, and (3) investor risk aversion. For convenience, the result will be

35. "Short selling" is the practice of selling a borrowed security in the hope that the price will soon fall, and the seller will be able to repurchase the security more cheaply in the market when the time comes to return it to its original owner. Short selling thus amounts to a bearish bet on a price decline that increases the "supply" of the borrowed security bulls can purchase. In real markets, short sellers generally face a variety of significant legal and practical obstacles. See infra text accompanying note 40.

36. See, e.g., BREALEY \& MYERS, supra note 15, at 195-203 (discussing conventional CAPM but not HEAPM); MALKIEL, supra note 15, at 220-39 (same).

37. For examples of asset pricing models that modify CAPM to achieve equilibrium prices under conditions of disagreement, see J.M. Harrison and David Kreps, Speculative Investor Behavior in a Stock Market with Heterogeneous Expectations, 92 Q.J. ECON. 323 (1978); Robert Jarrow, Heterogeneous Expectations, Restrictions on Short Sales, and Equilibrium Asset Prices, 35 J. FIN. 1105 (1980); Lintner, Diverse Judgments, supra note 33; Joram Mayshar, On Divergence of Opinion and Imperfections in Capital Markets, 73 AM. ECON. REV. 114 (1983); Miller, Risk, supra note 9; Ramon Rabinovich and Joel Owen, NonHomogeneous Expectations and Information in the Capital Asset Pricing Model, 33 J. FIN. 575 (1979); Sharpe, Disagreement, supra note 33; Treynor, supra note 33; Hal R. Varian, Divergence of Opinion in Complete Markets: A Note, 40 J. FIN. 309 (1985); Joseph T. Williams, Capital Asset Prices with Heterogeneous Beliefs, 5 J. FIN. ECON. 219 (1977).

For examples of legal scholarship exploring the policy implications of these models, see Richard A. Booth, Discounts and Other Mysteries of Corporate Finance, 79 CAL. L. REV. 1053 (1991); Stout, Takeover Premiums, supra note 17; Lynn A. Stout, How Efficient Markets Undervalue Stocks: CAPM and ECMH Under Conditions of Uncertainty and Disagreement, 19 CARDOzo L. REV. 475 (1997) [hereinafter How Efficient Markets Undervalue].

38. Miller, Risk, supra note 9.

39. Holman W. Jenkins, Jr., Business World: Short Sellers are People Too!, WALL ST. J., Jan. 29, 2003, at A19. 
referred to herein as the Heterogeneous Expectations Asset Pricing Model ("HEAPM").

The HEAPM begins, of course, by assuming that investors hold disagreeing opinions about the expected future risks and returns associated with particular securities. The model then assumes two forms of market imperfection. The first is restrictions on short selling. Although this assumption is extreme, it reflects an important reality of actual securities markets. In theory, bearish investors can participate in securities markets by borrowing securities to sell, purchasing put options, or selling securities futures. In practice, investors who try to adopt such shorting strategies face significant legal and practical hurdles. ${ }^{40}$ The result is that short sellers have only limited influence on prices in most markets. Readers who doubt this observation might simply ask themselves: how much of my own portfolio is in short positions?

Once we modify the CAPM to assume that investors disagree and that short sales are restricted, we produce an interim asset pricing model that predicts that individual investors with heterogeneous opinions about stock values will prefer to buy those individual stocks each believes are underpriced and avoid those stocks each perceives as overpriced. Since different individuals view different securities as under- and overpriced, any particular security will tend to be held by the particular individuals who subjectively place the highest value on it. Indeed, if the market is otherwise perfect (e.g., no transactions costs, no wealth limitations, no risk aversion) the entire stock of a firm's shares will end up in the hands of the single individual who subjectively values the stock most highly.

Of course, this prediction is not borne out in real securities markets. Hence, the HEAPM's third assumption (shared with the CAPM): that investors are risk averse. A risk averse investor will hesitate before putting all her wealth into a single asset, because such a strategy requires her to endure firm-specific, diversifiable risk that she could avoid by holding a more-diversified portfolio. Thus, risk aversion eventually will lead an investor to stop buying a particular security even if she still believes it to be underpriced. What might induce her to buy more? Lowering the price, which makes the security seem like an even better bargain, creating a subjective "risk premium" to compensate her for

40. See generally Charles M. Jones \& OWEN A. Lamont, Short SAlE Constraints and Stock RETURNS I (Center for Research in Security Prices Working Paper No. 533, 2001), available at http://papers.ssm.com/abstract=281514 (last visited Aug. 20, 2003); ELI OFEK, MATTHEW RICHARDSON, AND ROBERT F. WHITELAW, LIMITED ARBITRAGE AND SHORT SALES RESTRICTIONS: EVIDENCE FROM THE OPTIONS MARKETS (NBER Working Paper No. W9423, 2003), available at http://www.nber.org/papers/w9423 (last visited Aug. 20, 2003); Michael Powers, David Schizer, \& Martin Shubik, Market Bubbles and Wasteful avoidance: TaX and Regulatory Constraints on Short Sales (Columbia Law \& Econ., Working Paper No. 217, 2003), available at http://papers.ssm.com/abstract=391020 (last visited Aug. 20, 2003); Lynn A. Stout, Why the Law Hates Speculators: Regulation and Private Ordering in the Market for OTC Derivatives, 48 DUKE L.J. 701, 729-30, 757 (1999).

As an example of the difficulties associated with short selling, bears who borrow stock to sell short often have difficulty finding willing lenders, and also must engage in four transactions (a borrowing, a sale, a repurchase, and a return) to earn a profit. In contrast, bulls only need to arrange two transactions (a purchase and sale). Bears who instead try to short by trading futures and options find such trading is heavily regulated, and they must also often trade in standardized contracts with fixed expiration dates that may force them to liquidate their positions before they would like. Moreover, some kinds of securities futures and options cannot be traded legally at all (for example, until quite recently, single stock futures). To offer yet another example of how short selling is more difficult than going long, many important market participants, such as mutual funds, are legally prohibited from short selling in many circumstances. 
the increased diversifiable risk she must suffer if she increases her holdings. Lowering the price may also make the stock attractive to other, relatively less optimistic investors.

The HEAPM accordingly predicts that even at a very high price, a firm may be able to sell a small amount of stock to a small number of relatively optimistic investors. But if the firm wants to sell more shares, it must lower the price. Lowering the price increases demand for the stock both because less optimistic individuals who do not already own it become interested and decide to buy, and because the existing, more optimistic but riskaverse shareholders will be willing to purchase more shares. The result is a classic, downward-sloping demand function for equity securities.

The CAPM's prediction of the downward-sloping demand is important, because it creates an opportunity for empirical tests of the predictive power of the HEAPM vis-à-vis its homogeneous-expectations ancestor, the CAPM. The HEAPM's notion that investor demand for a stock is downward-sloping might seem plausible, even obvious, to nonexperts. Among finance economists, however, it is (or, more accurately, once was) a form of heresy. This is because the standard CAPM, when combined with the ECMH, predicts that all stocks should be accurately priced and no stock should be a bargain relative to any other. Thus all stocks should be perfect substitutes. If all stocks are perfect substitutes, the demand for a particular stock should be perfectly elastic, and the demand curve for that stock correspondingly flat. Raising the price above the level set by an efficient market would cause investors to refuse to purchase any shares at all, while lowering the price below market would create infinite demand.

This prediction of a flat demand curve ultimately is an artifact of the CAPM's underlying assumption of investor homogeneity. (If all investors agree on what a stock is worth, inevitably all will want to buy at a price below that value, and sell at a price above that value.) As finance theorists have published more and more papers exploring asset pricing under conditions of expectations heterogeneity, the theoretical fragility of the prediction of perfectly flat demand accordingly has become more apparent. ${ }^{41}$ Equally important, empirical studies have found overwhelmingly that the demand curves for stocks in fact slope significantly downwards. 42

41. See, e.g., sources cited supra note 37.

42. See, e.g., Laurie Simon Bagwell, Dutch Auction Repurchases: An Analysis of Shareholder Heterogeneity, 47 J. FIN. 71 (1992); Karl B Diether, Christopher J. Malloy, \& Anna Scherbina, Differences of Opinion and the Cross Section of Stock Returns, 57 J. FIN. 2113 (2002); (forthcoming 2003); Aditya Kaul, Vikas Mehrotra \& Randall Morck, Demand Curves for Stocks Do Slope Down: New Evidence from an Index Weights Adjustment, 55 J. FIN. 893 (2000); Claudio Loderer, John Cooney \& Leonard D. Van Drunen, The Price Elasticity of Demand for Common Stock, 46 J. FIN. 621 (1991); ElI OFEK \& MATTHEW RICHARDSON, THE IPO LOCK-UP PERIOD: IMPLICATIONS FOR MARKET EFFICIENCY AND DOWNWARD SLOPING DEMAND CURVES (2000), available at http://papers.ssm.com/abstract=207908 (last visited Aug. 20, 2003); Andrei Shleifer, Do Demand Curves for Stocks Slope down?, 41 J. FIN. 579 (1986).

The significance of one category of empirical studies, index-inclusion studies, has been questioned on the theory that even if the results are consistent with downward-sloping demand, researchers did not adequately exclude other possible explanations. Such criticisms do not apply to Laurie Simon Bagwell's pioneering reconstruction of actual demand curves from Dutch auctions, supra. See also OFEK \& RICHARDSON, supra (arguing that price effects of lock-up expirations cannot be explained away as information-based); BARBERIS \& THALER, supra note 23, at 41-42 (citing numerous other empirical studies that find support for the HEAPM that cannot be explained as a result of information signals).

In contrast to the extensive empirical literature that supports downward-sloping demand, there is very little evidence that supports a horizontal demand function. Most commentators who subscribe to horizontal 
Such empirical findings provide strong support for the claim that, in many respects, the HEAPM does a better job of predicting how actual markets behave than the CAPM does. They also highlight, however, one of the most important lessons to be learned from the new finance: if investors have heterogeneous expectations, the market price of a stock may change for a variety of reasons unrelated to any change in the value of the underlying company.

As an intriguing example of how this may happen, consider an explanation that has been recently offered by several scholars for the late 1990s price bubble in technology company stocks. ${ }^{43}$ This explanation focuses on the role of uncertainty in fostering investor disagreement. Laypersons often treat risk and uncertainty as synonyms. Finance economists, however, use the two words to describe different phenomena. "Risk" describes variation when the probabilities of possible outcomes are known: for example, a coin toss is risky but not uncertain because, although we do not know whether the coin will come up heads or tails, we know the probability of either event is fifty percent. ${ }^{44}$ Stock returns, in contrast, are subject to both risk and uncertainty. We not only do not know whether a particular stock's price will go up or down-we do not know with certainty the probability of either event. Investors' increased ignorance about the future leads to greater disagreement about stock values. Stock returns are subject to greater uncertainty in some time periods than in others (e.g., during times of political upheaval or rapid technological change). During these periods, investors' increased ignorance about the future leads to greater disagreement about stock values. In lay terms, where investors

demand rely solely or primarily on a three-decade-old study by Myron Scholes. Myron Scholes, The Market for Securities: Substitution Versus Price Pressure and the Effects of Information, 45 J. Bus. 179 (1971); see, e.g., BREALEY \& MYERS, supra note 15, at 376 (asserting flat demand curve in reliance on Scholes' work); West $v$. Prudential Securities, Inc., 282 F.3d 935, 939 (7th Cir. 2002) (making judicial finding that demand curve is flat while citing only Scholes and Brealey \& Myers). Scholes' study found that secondary distributions of stock by large shareholders averaging two percent of outstanding shares were accompanied by a two percent price decline, suggesting significantly inelastic demand. Scholes, supra, at 193-94. Scholes concluded, however, that this finding was not evidence of downward-sloping demand because the size of the distribution was not correlated with the magnitude of the price change. Id. at 195. Subsequent studies of block trading have found different results. See, e.g., Alan Kraus \& Hans R. Stoll, Price Impacts of Block Trading on the New York Stock Exchange, 27 J. FIN. 569, 582-83, 586 (1972) (noting that their results were different from Scholes'); W. H. Mikkelson \& M. M. Partch, Stock Price Effects and Costs of Secondary Distributions, 14 J. FIN. ECON. 165 (1985) (same).

43. See Eli Ofek \& Matthew Richardson, DotCom Mania: The Rise and Fall of Internet Stock Prices, $58 \mathrm{~J}$. FIN. 113 (2003) (linking the internet bubble to lockup expirations and insder trading); JOSE A. SCHEINKMAN \& WEI XIONG, OVERCONFIDENCE, AND SPECULATIVE BUBBLES (2003), available at http:papers.ssm.com/abstract $=298865$ (last visited Aug. 20,2003) (providing timeline model of bubbles caused by overconfidence and agent disagreements regarding asset prices); LyNN A. STOUT, StOCK Prices AND SOCIAL WeAlth 23-24, Harvard Law and Economics Discussion, Working Paper No. 301 (2000), available at http://papers.ssrn.com/abstract= 249991 (last visited Aug. 20, 2003) (explaining the failure to reflect corporate value in stock prices based on the complex relationship between stock price and social wealth).

The HEAPM suggests other factors that may have contributed to the bubble as well. For example, share repurchases may have restricted the supply of available stock, see infra text accompanying note 50 (discussing effect of changes in supply on prices), while the demand function was shifted outward as a result of the influx of middle-aged and newly-wealthy "Baby Boom" investors into the market during the 1980s and 1990 s, see infra note 51 (discussing aggregate demand). Of course, the demand-shifting process can work in reverse, something that may not bode well for retiring boomers.

44. See supra text accompanying note 30 (discussing risk). 
formerly held opinions ranging from pessimistic to optimistic, greater uncertainty permits opinions ranging from wildly pessimistic to wildly optimistic. ${ }^{45}$

If short sales are restricted, however, only the optimists' views are likely to influence the market price. ${ }^{46}$ The HEAPM consequently predicts that, other things being equal, stocks of highly-speculative firms whose futures are uncertain should trade at higher prices (relative to their expected returns and risks) than the stocks of more-stable firms whose futures are more foreseeable. ${ }^{47}$ It also predicts that an increase in overall economic uncertainty, by increasing the dispersion of investors' subjective opinions, can increase stock prices even when the average investor's opinion of the market's value is unchanged.

This analysis can be applied to the technology stock bubble of the late $1990 \mathrm{~s} .{ }^{48}$ In brief, the development of the Internet and other new technologies promised to increase corporate profits, explaining some of the run-up in stock prices. But the sudden appearance of a new, information-based economy also made it far more difficult for investors to predict exactly what any single firm's future might be. Corporate America clearly was going to evolve, but how far and to whose benefit? Business firmsespecially start-ups and those in the information technology industry-were suddenly operating in an economic environment that was far more uncertain than it was just a few years before. Given increased investor disagreement and short sales restrictions, the predictable result was an increase in stock prices-especially for start-ups and information technology firms.

As this discussion suggests, the HEAPM offers insights into empirical market phenomena that are difficult if not impossible to explain using the standard CAPM. The discussion thus far has considered only two such phenomena: empirical evidence of downward-sloping demand and possible causes of the tech stock bubble. Yet, the HEAPM explains a number of other market puzzles as well, including: why many investors do not fully diversify; 49 the price-shifting effects of share issues and repurchases; ${ }^{50}$ the remarkably large premiums paid to target shareholders in corporate

45. Increasing uncertainty increases the curvature of the demand function. If the supply of available shares is relatively limited, so that the supply function tends to intersect the demand function in the upper regions of the demand curve, increasing the curvature of the demand curve will tend to increase market price.

46. This assumes that the available supply of a particular stock is limited, so that only a small fraction of the total pool of investors is likely to buy it. In such a case, even the most-pessimistic investor in the optimistic subset who buy the stock will be more optimistic than the average investor.

47. See infra text accompanying note 53 (discussing high-beta anomaly.)

48. See sources cited supra note 43.

49. See Stout, How Efficient Markets Undervalue Stocks, supra note 37 (discussing how heterogeneous expectation explains why investors do not fully diversify).

50. If the investor demand function is downward-sloping, a corporation that issues additional shares is likely to find, other things being equal, that the result is a decline in the market price for shares. This is because issuing new shares increases the supply available, requiring the issuer to appeal to more pessimistic investors in order to clear the market. Stout, Takeover Premiums, supra note 17, at 1251. Of course, the process works in reverse. Reducing the supply of outstanding stock, for example, through a corporate share repurchase program, tends to raise price. See Jesse M. Fried, Insider Signaling and Insider Trading with Repurchase Tender Offers, 67 U. CHI. L. REV. 421, 434-36 (2000) (discussing this possibility).

This observation suggests that, in addition to market uncertainty, see supra text accompanying notes 43-48, corporate repurchases may have contributed to the recent market bubble. In the late 1990s, even as new firms were adding to the total supply of outstanding stock through a lively IPO market, seasoned corporations 
takeovers; 51 and a wide variety of so-called market "anomalies." 52 (One of the most interesting of these anomalies is the "high-beta" effect, a finding that firms characterized by very high levels of market risk do not, as the CAPM predicts, enjoy proportionately higher earnings. While obviously inconsistent with the CAPM, the result can be explained under the HEAPM if greater risk is correlated with greater uncertainty.). ${ }^{53}$

The HEAPM does more than shed light on hitherto-unsolved market mysteries, however. It also seriously undermines the theoretical foundations of the claim that stock prices in an informationally efficient market will be fundamental value efficient as well. The HEAPM accordingly severs the supposed link between efficient market prices that respond quickly to new information and accurate market prices that reflect expected risks and returns. After all, in a world where investors disagree about the value of a particular security, market price is nothing but the value opinion held by the most pessimistic member of the optimistic subset of investors who choose to hold the security. Why

were pursuing an even larger program of share repurchases. From 1997 through 2000 , for example, U.S. corporations repurchased nearly $\$ 300$ billion more in equity than they issued. See Board of Governors of the Federal Reserve System, Flow of Funds Accounts of the United States: Flows and Outstandings Fourth Quarter 2001, tbl. F.213, line 1, at 45 (Mar. 7, 2002), available at http://federalreserve.gov/releases/Zi/20020307 (last visited Aug. 20, 2003) (showing net equity issues by corporations between 1997 and 2000). They also paid nearly another 1.4 trillion dollars in stock dividends, which are economically equivalent to share repurchases. See id. at tbl. F-7, line 22 at 13 (showing dividends paid out of corporate profits); see generally BREALEY \& MYERS, supra note 15 , at $439-43$ (discussing dividend and repurchase equivalency). The end result was that, during this period, U.S. firms effectively reduced the supply of stock available for purchase by public investors by more than 1.7 trillion dollars, nearly $10 \%$ of the market's total 1999 equity capitalization of $\$ 1.95$ trillion, see Federal Reserve Flow of Funds, supra, at tbl. L-213, line 1, at 90 (showing market capitalization).

51. In a typical takeover the bidding firm pays a significant premium-50\% is not unusual-for the target's shares. Meanwhile, the market price of the bidding firm's shares usually remains largely unchanged. Some theorists conclude that takeover premiums are prima facie evidence that acquiring firms expect to dramatically improve the economic performance of the target companies. This optimistic view runs aground, however, on accounting evidence that takeover targets tend to become neither more nor less profitable after being acquired. There also remains the puzzle of why, if takeovers create such gains, they accrue only to the target's shareholders. See generally Stout, Takeover Premiums, supra note 17, at 1262-63.

Heterogeneous expectations pricing models offer an easy and elegant explanation for large takeover premiums by suggesting they are, to a significant degree, artifacts of downward-sloping demand curves. The investor who wants to purchase only a single share in a particular company only needs to offer a price sufficient to satisfy the marginal, relatively pessimistic shareholder. But a takeover bidder who wants to purchase $51 \%$ or more of a target must inevitably "work his way up" a sloping demand function, paying ever higher prices to ever more optimistic shareholders. See supra text accompanying notes 41-42. Alternatively, one can think of the arrival of a takeover bidder into the market as shifting the demand curve outward by increasing the aggregate wealth of the investors competing for the firm's limited supply of outstanding stock.

Downward-sloping demand accordingly can explain both why bidders pay large premiums, and why the price of the bidding company's stock on average remains unchanged. It also suggests that we should hesitate to draw any conclusions about the efficiency of takeovers based on premia alone. Stout, Takeover Premiums, supra note 17, at 1275. For other reasons to question the efficiency of takeovers, see Lynn A. Stout, Do Antitakeover Defenses Decrease Shareholder Wealth? The Ex Post/Ex Ante Violation Problem, 55 STAN. L. REV. 845 (2002).

52. See Stout, How Efficient Markets Undervalue Stocks, supra note 37, at 487 (discussing how HEAPM can explain many anomalies).

53. See Miller, supra note 9, at 1155 (discussing anomaly and how HEAPM can explain it). As noted earlier, the HEAPM predicts that the stocks of speculative firms whose futures are uncertain should trade at higher prices than stocks of firms whose futures are more predictable. See supra text accompanying notes 45 47. 
assume that relatively-pessimistic optimist's opinion is correct?

In The Mechanisms of Market Efficiency, Gilson and Kraakman suggest an answer in their discussion of what they call "uninformed" trading. ${ }^{54}$ They begin by recognizing that even if all investors had equal access and ability to use to all available information about securities' expected risks and returns, one important category of information remains fundamentally "unavailable"-knowledge of what is going to happen in the future. As a result, investors can and do disagree in their forecasts. It is worth emphasizing that disagreement over the future is not a minor matter in a securities market. Securities are nothing more than claims to a stream of future income, so minor disagreements in predictions can lead to major disagreements about valuations. Nevertheless, Gilson and Kraakman suggest investors' divergent forecasts may not lead to inaccurate securities prices, so long as mistakes in forecasting are random. As they put it, "the random biases of individual forecasts will cancel one another out, leaving price to reflect a single, best-informed aggregate forecast." 55

Gilson and Kraakman's discussion of "uninformed" trading (in essence, trading by investors with heterogeneous expectations) accordingly relies on the heuristic that in a world where actors make mistakes haphazardly, unwarranted bullishness and bearishness tend to correct each other. Thus, the average opinion stands a better chance of being accurate than any single actor's opinion. This heuristic reflects a time-honored tradition in economic thought. ${ }^{56}$ Nevertheless, there is reason to suspect that it cannot be applied to securities markets safely.

This is because investor mistakes, as reflected in securities prices, are subject to several sources of bias. Consider the observation, offered earlier, that in a perfect market, bullish and bearish views do not "cancel each other out" in equilibrium-rather, they prevent equilibrium. ${ }^{57}$ If investors disagree in their forecasts as Gilson and Kraakman assume (and even the most casual empiricism confirms), we must accordingly rely on some form of market imperfection to obtain a market price. And many market imperfections can be expected to introduce bias into prices. 58

As an example, consider the bias inherent in the HEAPM's assumption of short sales restrictions. This realistic assumption helps explain how equilibrium prices are possible. At the same time, however, it suggests that investor misvaluations, as reflected in securities prices, will tend to be skewed toward optimism. 59 This does not mean that securities, as a class, are necessarily overpriced-the extent to which marginal investor

54. See Gilson \& Kraakman, supra note 3, at 580-83.

55. Id. at 581 .

56. Gilson and Kraakman, for example, develop their argument from an earlier paper by Robert Verrechia. Gilson \& Kraakman, supra note 3, at 582. See also Fama, supra note 20, at 388 (arguing that "disagreement among investors ... does not in itself imply market inefficiency unless there are investors who can consistently make better evaluations ...").

57. See supra text accompanying notes 35-36.

58. If a particular form of cognitive bias is present in a large portion of the investing population, this may also introduce systematic bias into prices. See infra text accompanying notes 114-37 (discussing behavioral finance).

59. It may also explain the results of studies finding that market developments that make shorting easier, e.g., the introduction of options trading, decrease market prices. See, e.g., Bartley R. Danielsen, Why Do Options Depress Stock Prices? A Study of Diminishing Short-Sale Constraints, J. FIN. \& QuanT. ANAL. (forthcoming 2003). 
opinion is subject to optimistic bias will be influenced by other factors as well, such as the supply of the security at issue and the availability of substitutes. ${ }^{60} \mathrm{It}$ does mean, however, that there is no reason to presume that a market price set by the marginal investor's opinion of value mirrors the average opinion of value. ${ }^{61}$

Nor is there reason to assume that, even if prices reflected average opinion, the average opinion of value is equivalent to the best opinion of value. ${ }^{62}$ The concept of subjective disagreement invites us to consider whether, when investors disagree, there is reason to suspect that some are more likely to be right than others. ${ }^{63}$ As Gilson and Kraakman discuss, if individual traders' estimation errors are randomly distributed within a fixed range, the average of all investors' valuations is more likely to capture the economic reality of the firm than the valuation of any single investor plucked at random. ${ }^{64}$

But why pluck an investor at random? Some market participants can acquire, process, and verify available information about securities values more cheaply and easily than others can. Professional analysts, for example, likely make systematically superior estimates of value compared to most of the lay investors who also participate in the market. Of course, these individuals often have incentive to withhold or distort their views. ${ }^{65}$ Nevertheless, their unadulterated estimates of stock value likely come closer to the truth than the average investor's estimate does.

In other words, the average investor's opinion indeed may be better than any random investor's opinion is likely to be. However, it is not as good as the most expert opinion. By the same token, even if market price were set by the average opinion of a particular security's value (a questionable assumption when bias exists), that average opinion would not necessarily mirror the best possible estimate of value in light of all available information. 66

The end result is that, once we recognize that the concept of fundamental value efficiency depends not only on the ECMH but also on some asset pricing model, most commonly CAPM, and that the CAPM itself is premised on investor homogeneity, the argument that efficient market prices reflect the best possible estimates of securities' future risks and returns is in a shambles. Fundamental value efficiency is a theoretical rabbit pulled out of a hypothetical hat. If investors disagree in their forecasts, there is no $a$ priori reason to assume that securities prices will mirror the best possible estimates of their expected risks and returns. Nor is there good reason to be surprised by the increasing empirical evidence that, in fact, they do not.

60. See also Stout, Takeover Premiums, supra note 17, at 1248-49 (discussing why observation that prices are set by marginal investor does not necessarily imply systematic overpricing).

61. See id. at 1248,1288 (discussing role of marginal investor).

62. See id. at 1249, 1291-93 (discussing concept of best value).

63. See infra text accompanying notes 103-112 (discussing empirical evidence that some traders consistently outperform others in market).

64. See supra text accompanying notes 54-56.

65. See, e.g., Gretchen Morgenson, Telecom's Pied Piper: Whose Side Was He On?, N.Y. Times, Nov. 18, 2001, at Sec. 3, p. 1 (discussing aliegations that star Lehman Brothers research analyst Jack Grubmann made optimistic recommendations regarding telecommunications companies in return for those companies' funneling investment banking business to Lehman).

66. See also infra text accompanying notes $90-93$ (discussing why better informed traders cannot always profit from arbitrage); infra notes 103-112 (discussing evidence that some in fact do). 


\section{EFFICIENT MARKETS AND THE Limits OF ARBITRAGE}

Part II examines the question of whether securities markets are likely to be efficient in the fundamental value sense, so that securities prices reflect the best possible estimates of future risks and returns. It concludes that, under a wide variety of plausible circumstances, the answer is "no." As noted earlier, however, fundamental value efficiency is not the only possible understanding of market efficiency. Many commentators who employ the phrase "efficient market" (including, in much of their discussion, Gilson and Kraakman) seem to be relying instead on the alternative idea of informational efficiency-that prices respond so quickly to new information that it is impossible for traders to make trading profits on the basis of that information. ${ }^{67}$

It is important to understand that when finance economists define market efficiency in terms of the difficulty of making arbitrage profits, they have implicitly abandoned the more-powerful claim that efficient markets price securities accurately. This is because a market can be informationally efficient without also being fundamental value efficient. Suppose, for example, that the best (most informed) estimate of the value of Widget Corp. shares is $\$ 100$ per share. Because of short sales restrictions, however, all the stock of Widget is held by a relatively optimistic subset of all investors. The most pessimistic member of this optimistic subset is the marginal investor whose opinion determines marginal price. This marginal investor values her Widget stock at $\$ 110$ per share. The market price of Widget Corp. accordingly exceeds the best estimate of its value by ten percent.

Now, new information arrives which, all investors agree, indicates that Widget's earnings are about to double. In light of this new information, the best estimate of Widget's value is now $\$ 200$. Yet, because the market price of Widget is set by a relatively optimistic marginal investor who overestimates the value of Widget by ten percent, the market price of Widget in light of the information about doubled earnings now leaps to $\$ 220$.

This example illustrates how a market can respond near-instantaneously to new information without producing prices that accurately mirror best estimates of fundamental value. ${ }^{68}$ Thus, once we abandon the CAPM, it is possible to imagine a market that is efficient in the informational sense, but not efficient in a fundamental value sense. Indeed, it has become common for finance economists whose faith in fundamentalvalue efficiency has been beaten out of them by market events and the accumulating evidence on anomalies to retreat to this intellectual position. ${ }^{69}$ The idea of an

67. See, e.g., Gilson \& Kraakman, supra note 3, at 555.

68. Nor can savvy investors who recognize true value necessarily wring arbitrage profits from trading on the marginal investor's mistake. See infra text accompanying notes 90-93 (cataloging obstacles to arbitrage profits for investors who make best estimates of value).

69. See, e.g., BREALEY \& MYERS, supra note 15, at 377 ("While there remain plenty of unsolved puzzles, there seems to be widespread agreement that consistently superior returns are hard to attain."); MALKIEL, supra note 15, at 270-74 (conceding there is evidence that "future returns are, in fact, somewhat predictable," but arguing that "even if there is a dependable predictable relationship, it may not be exploitable by investors"); but see id. at 270-74 (suggesting that the October $1987 \mathrm{crash}$ might have been consistent with an efficient market because new information might have changed investors' views of the values of securities). See also KUHN, supra note 19, at 77-78 (discussing how scientists typically respond to mounting evidence of anomalies not by rethinking their accepted paradigms, but instead by devising "numerous articulations and ad hoc modifications 
informationally efficient market does not carry with it some of the more intoxicating implications of fundamental value efficiency (for example, that stock price is the best indication of share value for purposes of compensating executives, evaluating governance rules, or assessing the impact of hostile takeovers). ${ }^{70}$ It does, however, support other important ideas.

An example can be found in the great enthusiasm legal scholars and economists have shown in recent years for "event studies" that attempt to assess investors' views of the merits of changes in corporate law or policy by gauging whether, when the event is announced, share prices rise or fall. ${ }^{71}$ Event study researchers generally conclude that if announcement of an event is accompanied by a change in market prices, investors view the event as important "news" relevant to assessing share value. This idea, which presumes informational efficiency, shows signs of spreading beyond academics: courts have begun to rely on event studies to determine damages in securities fraud cases, and even whether or not a misstatement or omission was "material."72

The idea of informational efficiency, while less revolutionary than the idea of fundamental value efficiency, accordingly has had a significant effect on modern corporate policy and thinking. In light of this, it seems worthwhile to explore the extent to which securities markets are, in fact, informationally efficient.

Gilson and Kraakman's article provides an excellent starting point for this exploration. They note that one of the underlying puzzles of market efficiency is that information, like other resources, is costly. ${ }^{73}$ Moreover, the cost of acquiring, analyzing, and verifying different information varies substantially from investor to investor. Even when a particular piece of data is technically in the public domain, in many cases it is likely to be obtained and analyzed only by a small subset of all investors. Thus the fact that information may be "public" does not necessarily imply that all investors are actually aware of it. How, then, can market prices behave as if all investors know the information?

Much of the discussion in The Mechanisms of Market Efficiency is devoted to answering this question. ${ }^{74}$ In a detailed analysis, Gilson and Kraakman explore a number of explanations of how information known only to a small subset of investors can be quickly incorporated into market prices. One possibility is that the information gets into prices through the trading activities of the informed subset. For example, if informed

of their theory in order to eliminate any apparent conflict").

70. See, e.g., Stout, Takeover Premiums, supra note 17, at 1237 (discussing how belief in market's fundamental value efficiency has influenced corporate scholarship and policy).

It should be noted that, even under the conventional ECMH/CAPM, market price will not be the best indication of value if it does not incorporate available, but nonpublic, information. See supra note 24 (discussing concept of 'semistrong' market efficiency). It should also be noted that market price is by definition the best indication of share value for the investor who intends to sell her shares immediately, even absent fundamental value efficiency.

71. See generally A. Craig MacKinlay, Event Studies in Economics and Finance, 35 J. ECON. LIT. 13 (1997).

72. See generally Janet Cooper Alexander, The Value of Bad News in Securities Class Actions, 41 U.C.L.A. L. REV. 1421 (1994) (discussing use of event studies to calculate damages); Jonathan R. Macey et. al., Lessons From Financial Economics: Materiality, Reliance, and Extending the Reach of Basic v. Levinson, 77

VA. L. REV. 1017 (1991) (discussing use of event studies to determine materiality).

73. See Gilson \& Kraakman, supra note 3, at 593-97.

74. Id. at 569-79. 
professional traders buy large quantities, their transactions may drive prices upward through "price pressure." 75 Alternately, other, less well-informed investors may be able to extract the information from the informed traders' transactions through "price decoding" and "trade decoding." 76 In either case, informational efficiency depends on arbitrageurs' ability to quickly move prices. ${ }^{77}$

But can arbitrageurs, in fact, always quickly move prices? Put differently, how well do the market mechanisms identified by Gilson and Kraakman actually work? In the years immediately following the development of the ECMH, the theory was subject to extensive empirical testing as researchers analyzed how quickly prices responded to public announcements of stock splits, dividend changes, corporate mergers, and the like. In most cases, they found that prices seemed to respond to new information almost immediately, with most of the change occurring within hours or even minutes of an announcement. ${ }^{78}$ Hence, Professor Jensen's famous claim that "no other proposition in economics" had more empirical support than the efficient market theory. ${ }^{79}$

But consider for a moment the kind of information researchers initially used to test the efficient market hypothesis. Merger announcements and public reports of stock splits are both widely disseminated and relatively easy to understand. What happens when new information becomes available, but investors must invest substantial time, trouble, or money to get it? What happens when the information is technical and difficult to understand? Do prices still change within hours or minutes? ${ }^{80}$

Recent studies suggest that the answer to this last question may be "no."81 Many types of information highly relevant to assessing the economic health of firms appear to be incorporated into stock prices far more slowly and incompletely than the conventional view of market efficiency would suggest. Sometimes, it seems, the market's machinery can be rather creaky and cranky.

Consider the example of a study by Saeyoung Chang and David Suk of market reactions to the Wall Street Journal's weekly "Insider Trading Spotlight" column. ${ }^{82}$ Section 16 of Securities Exchange Act of 1934 requires a corporate officer, director, or

75. Id. at $570 \&$ n.67. As Gilson and Kraakman note, this idea is inconsistent with the claim that the demand for stock is perfectly elastic. See supra text accompanying notes 41-42.

76. Gilson \& Kraakman, supra note 3, at 573-79.

77. It should be noted that in even in a highly informationally efficient market, arbitrage trading cannot be expected to produce perfectly informed prices. Some degree of mispricing must persist in the market, or arbitrageurs would have no incentive to incur the costs associated with identifying and trading mispriced securities. Thus we should expect "an efficient amount of inefficiency" in the market. See generally Grossman \& Stiglitz, supra note 23. However, the lower the costs of acquiring information, the less informational inefficiency we should expect to see.

78. See BREALEY \& MYERS, supra note 15, at 358-60 (describing studies); Gilson \& Kraakman, supra note 3 , at 555-57 (same).

79. See supra text accompanying note 1 .

80. As Gilson and Krakman put it, one of the critical questions to be answered in assessing market efficiency is "[h]ow long does it take?" Gilson \& Kraakman, supra note 3, at 560 (emphasis in original).

81. See BREALEY \& MYERS, supra note 15, at 363-65 (discussing studies). Indeed, there was significant evidence that stock prices respond slowly to certain types of information at the time Gilson and Kraakman were writing. See Gilson \& Kraakman, supra note 3, at n.206 (citing and discussing studies of delayed price reaction).

82. Saeyoung Chang \& David Y. Suk, Stock Prices and the Secondary Dissemination of Information: The Wall Street Journal's "Insider Trading Spotlight" Column, 33 FIN. REv. 115 (1998). 
large shareholder who buys or sells shares in her own company to report such "insider trading" to the Securities Exchange Commission (SEC), where the report becomes available to the public. ${ }^{83}$ The market follows Section 16 reports closely, because corporate insiders are thought to have access to valuable information and knowledge about the firm which is not available to the public and so is not already reflected in market prices. ${ }^{84}$ The filing of a Section 16 report for a particular firm's stock accordingly is usually followed by an appropriate price change as Gilson and Kraakman's "trade decoders" get to work, buying on news that insiders are buying and selling on news that insiders are selling. Thus, a Section 16 filing converts formerly unavailable "private" information into available "public" information that can be incorporated into market price.

But how rapidly? Although the SEC generally makes Section 16 filings available to the public on same day they are received, to read them an interested investor must go to the SEC's reading room or subscribe to an online service. ${ }^{85}$ Alternatively, if the investor is willing to wait a few days, she can get the same information by buying a Wall Street Journal and reading the weekly "Insider Trading Spotlight" column. To examine the market's informational efficiency, Chang and Suk measured changes in stock prices at two different time periods after insiders filed Section 16 reports. First, they measured price changes on the day the reports were initially filed at the SEC. Then they measured changes on the day the reports were republished in the Wall Street Journal (on average, ten days later). Significant price changes were observed on both dates. ${ }^{86}$ This finding suggests that the market's initial response to the Section 16 filings was incomplete and delayed. ${ }^{87}$

A related and well-researched example of delayed market response to new information may be found in the widely-studied phenomenon of "post-earningsannouncement-drift." Studies have found that, when a corporation announces an unanticipated increase in earnings, the announcement tends to be followed by abnormal positive returns in the firm's stock over the next several months. Conversely, corporations that unexpectedly announce news of bad earnings see abnormal negative returns over an extended period. ${ }^{88}$ Researchers have puzzled over these results. Some have concluded that drift is evidence that the initial price response to the new earnings information is incomplete, and that the full implications of the new earnings information are digested by the market far more slowly than previously suspected. ${ }^{89}$

83. See generally ThOMAS LeE HAZEN, THE LAW OF SECURITIES REGULATION 626-54 (2d ed. 1990) (discussing $\$ 16$ of the Securities and Exchange Act of 1934).

84. In other words, these arbitrageurs believe that the market is only semistrong efficient, so they can earn arbitrage profits if they can "trade-decode" nonpublic information from insider trading. See supra note 24 (discussing semistrong efficiency), and text accompanying note 24 (discussing trade decoding).

85. Chang \& Suk, supra note 82 , at $115-17$.

86. $I d$.

87. See id. at 124 (concluding that "it may well be that if the initial disclosure... is not widely disseminated to the investing public, the secondary dissemination of the information can effect stock prices ...").

88. See Victor L. Bernard \& Jacob K. Thomas, Post-Earnings-Announcement Drift: Delayed Price Response or Risk Premium?, 27 J. ACCT. RES. 1, SUPP. at 5 (1989) (reviewing studies); see generally BREALEY \& MYERS, supra note 15, at 364-65 (reviewing studies).

89. Bernard \& Thomas, supra note 88 , at $4-5$. Some defenders of market efficiency argue that an 
What accounts for such a delayed and incomplete market response? A number of relatively recent papers suggest some answers, in the form of a number of factors that may, in the real world, limit the power that arbitrage enjoys in the world of theory. ${ }^{90}$

First, arbitrage is not a costless process. As Gilson and Kraakman explain in some detail, information is costly to acquire, process, and verify. ${ }^{91}$ Buying and selling securities also involves costs, especially when would-be arbitrageurs want to profit from bad news by selling short. (Indeed, in some cases the costs of short selling may be so high that arbitrage becomes effectively impossible.) ${ }^{92}$ Second, arbitrageurs, like the rest of us, enjoy access to only finite amounts of money. As a result, even the most successful "arb" will usually be able to afford to hold only a small percentage of a firm's outstanding stock, meaning that the subjective opinions of other, less well-informed investors can be expected (in accord with the HEAPM) to continue to have a "dampening" effect on the movement of market price. Third, arbitrageurs, like the rest of us, are also likely to be risk-averse, meaning they will hesitate to take a very large position that requires them to bear otherwise diversifiable firm-specific risk. Fourth, and perhaps most important, arbitrageurs likely recognize that they can only hope to profit from their superior information if the rest of the market eventually becomes aware of what the arb already knows, and also comes to agree with the arb's assessment of value. As they say on Wall Street, "a bargain that stays a bargain is no bargain." This is true even for individual arbitrageurs, who must worry that while they wait for other investors to come to agree with their assessments, something bad may happen to either the company or the economy as a whole. The problem of the "bargain that stays a bargain" is even more worrisome for pension and mutual fund portfolio managers, whose careers may depend on their last year's (or even their last quarter's) performance. The end result is that individual and institutional arbitrageurs alike face the risk that uninformed investors will stay uninformed, and that after they have taken a large position, the market may come to agree with their assessments of value only slowly, or not at all.

These realities of trading life suggest a picture of market efficiency-tentatively sketched out in Gilson and Kraakman's analysis 93 - quite different from the portrait painted in most basic finance texts. Basic texts tend to describe the process of information adjustment in efficient markets as binary, like flipping a switch. Information

alternative explanation for "post-earnings-announcement drift" is that the CAPM used to calculate abnormal returns is either incomplete or misspecified. See id. at 5 (studying and rejecting this explanation).

90. A growing literature explores the limitations to arbitrage that exist in real markets. See, e.g., BARBERIS \& Thaler, supra note 23, at 3-8 (discussing limits to arbitrage); ZHIWU ChEN, WeRver STANZL, \& MASAhIRo WATANABE, PRICE IMPACt COSTS AND THE LIMIT OF ARBITRAGE, International Center for Finance, Working Paper No. 00-66 (2001), available at http://ssrn.com/abstract=292267 (last visited Aug. 20, 2003) (analyzing profits where price-impact costs were taken into account); Gordon Gemmill \& Dylan C. Thomas, Noise Trading, Costly Arbitrage, and Asset Prices: Evidence from Closed End Funds, 57 J. FiN. 2571 (2002) (rejecting noise-trader risk as the cause of long-run discount and proposing arbitrage difficulty as leading to larger discounts); Richard Mendenhall, Arbitrage Risk and Post-Earnings Announcement Drift, J. BUS. (forthcoming 2003) (examining relationship between post-earnings announcement drift and the arbitrage risk viewed as a potential trading opportunity). See also infra note 145-146 (discussing arbitrage and noise trading).

91. Gilson \& Kraakman, supra note 3, at 597-609.

92. See supra text accompanying note 40 (discussing obstacles to short selling).

93. See Gilson \& Kraakman, supra note 3, at $609-13$ (discussing relationship between cost and distribution of information and the speed with which it is reflected in price). 
is either public or private, either "in" or "out" of the market price. 94

The observation that arbitrage is costly and imperfect offers a different perspective. Rather than resembling the flipping of a switch, the flow of information into prices may more closely resemble the flow of a fluid into a vessel. How full the vessel gets, and how quickly, depends on both the diameter of the channel through which the fluid flows (how widely the information is disseminated) and the viscosity of the liquid (how complex, technical, or difficult to understand the information may be). Information that is easy to understand and that is trumpeted in the business media-for example, merger announcements or news of a stock split-may be incorporated into market prices almost instantaneously. 95 But information that is "public" but difficult to get hold of, or information that is complex or requires a specialist's knowledge to comprehend, may take weeks or months to be fully incorporated into prices. Indeed it may never be fully incorporated at all.

This view of market efficiency as an imperfect and incremental process offers a number of important lessons. For example, as noted earlier, it has become a popular practice among scholars in recent years to gauge the significance of business developments by examining whether a particular occurrence is accompanied by a change in share prices. ${ }^{96}$ Such event studies frequently find that an apparently important corporate development-an unanticipated judicial opinion or statutory change, or the issuance of a misleading corporate statement-did not have a significant effect on share price. ${ }^{97}$ It can be tempting to conclude from this finding that investors deemed the event in question unimportant.

Event studies can be criticized for a variety of reasons. ${ }^{98}$ But an incremental model of market efficiency suggests we should be particularly reluctant to draw conclusions from event studies that fail to find any significant price response to the studied event. Perhaps the market failed to react because the event was not, in fact, significant enough to change an informed investor's view of the firm's value. But perhaps the price didn't change because most investors - unwilling to invest the resources necessary to detect or understand the implications of the event-simply remained uninformed and unaware of it. In other words, false negatives are likely to be an endemic problem in event studies. ${ }^{99}$

Similarly, the possibility of informational inefficiency carries potentially important

94. See supra text accompanying notes 20-24.

95. See Gilson \& Kraakman, supra note 3, at 568-69 (discussing "universally informed trading").

96. See supra text accompanying notes 71-72 (discussing event studies).

97. See, e.g., Peter Dodd \& Richard Leftwich, The Market for Corporate Charters: "Unhealthy Competition" versus Federal Regulation, 53 J. Bus. 259 (1980) (finding no market reaction to corporate decision to reincorporate in Delaware); Roberta Romano, The Political Economy of Takeover Statutes, 73 VA. L. REV. 111, 181-85 (1987) (testing for market reaction to legislative adoption of antitakeover statutes and finding none); Elliott J. Weiss \& Lawrence J. White, Of Econometrics and Indeterminacy: A Study of Investors * Reactions to "Changes" in Corporate Law, 75 CAL. L. REv. 551 (1987) (testing market reaction to unanticipated Delaware Supreme Court decisions, and finding none).

98. For example, it may be uncertain when a planned change in corporate law or practice first becomes known to the public. See Romano, supra note 97, at 182 (discussing problem in context of anti-takeover statutes).

99. This does not mean event studies are value!ess. The finding of a statistically significant market response may be strong evidence that the event in question has changed investors' views of the value of the underlying firm. 
implications about the significance of accounting treatments. Business and accounting professionals frequently talk and act as if pro forma financial statements, the designation of events as special charges, and other changes in accounting treatments influence stock prices, even though such "window dressing" does not change the economic reality of the firm, and even though this should be obvious to a careful and sophisticated observer. Thus, corporate executives practice the art of "earnings management" while regulators try to rein them in. ${ }^{100}$ Academics sometimes sniff at these battles on the theory that in an efficient market, accounting window dressing is ineffective and should not be cause for concern. ${ }^{101}$ An incremental model of market efficiency suggests, however, that the managers and regulators may be right. If large numbers of investors are unwilling to invest the effort necessary to understand and follow accounting conventions, and if the opinions of these ignorant investors influence market prices, window dressing can work.

Finally, and perhaps most obviously, the possibility of informationally inefficient markets undermines perhaps the most central implication of efficient market theory-that you can not "beat the market" by trading on available information. To see why, consider a scenario in which Widget Corp. stock is initially trading at $\$ 100$ per share. Widget issues an earnings statement that contains, buried in a footnote, the disclosure that the company has just granted its top executives stock options that are likely to have a significant dilutive effect on the company's shares, reducing their expected value to only $\$ 90$. However, the footnote is buried so deeply, and written in language so technical and obtuse, that only the most careful and sophisticated observer can read and appreciate this newly "available" information. As a result the market price of Widget responds to the new information slowly and incompletely. Six months after the statement is issued, Widget stock has only declined to $\$ 95$ (not $\$ 90$ ) per share.

In theory, such a delay in market response presents a tempting opportunity for a careful and sophisticated investor to make money by selling Widget's stock short in anticipation of its decline. As discussed above, it is important not to exaggerate the value of this opportunity: stock trading inevitably involves transaction costs, and short-selling can be even more costly than other forms of trading. Moreover, any arbitrageur who tries to reap a profit from an anticipated delay in market response must worry either that the market will never appreciate the significance of the new information ("a bargain that stays a bargain is no bargain") or it will recognize its significance at such a distant point in the future that the risk associated with taking a long-term, undiversified position in Widget stock outweighs the likely speculative return. This concern is especially great for professional investment advisors and mutual fund portfolio managers, whose careers may depend on their short-term results. ${ }^{102}$

100. For an update on the current state of the war, see David Henry, Ouch! Real Numbers, BUs. WK. 72 , Mar. 24, 2003 (describing conflict); see also Paul K. Chaney \& Craig M. Lewis, Earnings Management and Firm Valuation Under Assymetric Information, 1 J. CORP. FIN. 319 (1995) (describing the widely-held belief that corporate officers manage earnings).

An example of the debate over accounting "window dressing" can be found in the debate over whether corporations should be required to "expense" the cost of employee option grants in their earnings statements, or whether it should suffice if firms simply describe the structure of their options plans in the footnotes to the financial statements. See Lingling Wei, Flexible Stock-Option Rules Are Planned, WAll ST. J., Oct. 8, 2003, at B12 (describing debate). If the market is informationally efficient, it should make no difference.

101. See, e.g., BREALEY \& MYERS, supra note 15, at 372 (arguing that "there are no financial illusions").

102. See E. S. Browning, Stock Rally Seems Like Deja Vu, WALL ST. J., Jul. 14, 2003, at Cl (noting that 
Nevertheless, an incremental model of market efficiency implies that, in principle, some traders can reap some arbitrage profits from trading on some forms of publicly available information. What happens in practice? During the heyday of the ECMH, it was widely accepted among academics that studies had proven it was impossible to consistently beat the market, and that investment professionals who claimed they could were lying, either to their customers or to themselves. ${ }^{103}$ This view was based largely on a series of studies in the $1960 \mathrm{~s}$ that found that mutual funds, which are run by professional portfolio managers, underperformed market indexes. ${ }^{104}$ If these professionally-managed, sophisticated institutional investors could not beat the market by trading on publicly available information, the argument went, neither could anyone else.

Closer inspection suggests a weakness in this analysis. Mutual funds and other institutions own about half of all equity securities and account for an even higher portion of all stock trading. ${ }^{105}$ It would hardly be surprising to find that mutual funds on average fail to beat the market, when mutual funds on average very nearly are the trading market. Nevertheless, it should be noted that some recent studies have found that mutual funds outperform market indexes enough to offset their research and trading expenses. ${ }^{106}$ More important, whether or not mutual funds beat the market on average, some individual mutual fund managers rather consistently have been able to do so. ${ }^{107}$ (Warren Buffett is a renowned example.). ${ }^{108}$

A recent study finds a similar pattern among individual traders. ${ }^{109}$ Coval et al. examined the transaction records of over 110,000 individual investment accounts at a major discount brokerage. Not surprisingly (especially in light of the evidence that many

mutual fund and hedge fund managers "are judged on their ability to stay ahead of competitors, month by month, quarter by quarter").

103. See, e.g., MALKIEL, supra note 15, at 166 ("Some academicians have gone so far as to suggest that a blindfolded monkey throwing darts as the Wall Street Journal can select stocks with as much success as professional portfolio managers.")

104. Richard A. Ippolito, On Studies of Mutual Fund Performance, 1962-1991, 49 F. ANAL. J. 42, 42 (1993).

105. See NYSE Factbook Online, Holdings of Corporate Equity in the U.S. by Type of Institution, available at http://www.nysedata.com/factbook/viewer_edition.asp? mode=table\&key=108\&category=12 (last visited Aug. 20, 2003) (showing that institutions held 47\% of corporate equity in 2000 and $48.3 \%$ in 2001); see also Stout, Casinos, supra note 23 , at $\mathrm{n} .88$ (noting that mutual funds turn over their portfolios at a significantly higher rate than the market as a whole).

106. Ippolito, supra note 104, at 42; see also BREALEY \& MYERS, supra note 15, at 361 (noting that while some studies have found that funds on average outperform market, others have reached contrary results). If, as some studies find, mutual funds are outperforming the market enough to cover their expenses, the natural implication is that some other group-individual investors seem likely-is systematically underperforming the market. In fact, evidence supports this proposition, although at the same time some individual investors appear able to earn consistently above-market returns. JOSHA D. COVAL, DAVID A. HIRSHLEIFER, \& TYLER G. Shumway, CAN INDIVIDUAL INVESTORS BEAT THE MARKET?, Harvard NOM Research Paper No. 02-45 (2002), available at http://ssrn.com/abstract $=364000$, at $n .4$ (last visited Aug. 20, 2003) (finding that while individual investors as a class under-perform mutual funds, some individuals consistently outperform the market).

107. See Stout, Efficient Markets, supra note 37, at 476-77 (discussing evidence of "hot hands" effect); Coval et al., supra note 106, at n.5 (same).

108. Stout, Efficient Markets, supra note 37, at 477.

109. Coval et al., supra note 106. 
mutual funds slightly outperform the market before expenses), ${ }^{110}$ the authors found that individual traders on average underperform the market net of expenses. ${ }^{111}$ This average, however, obscured a striking pattern. While most individual investors did not seem able to outperform the market, the top ten percent seemed to be able to do so with some consistency. As the authors concluded, "some individual investors have superior investment skills ... . This evidence does not support the efficient market hypothesis." 112

More-recent empirical studies consequently reveal that at least some traders do, in fact, beat the market with some consistency. This is not to say the job is easy. As noted earlier, arbitrage is always costly, and often risky as well: arbitrageurs must hope the market reacts slowly enough for them to be able to get in at a discount, but quickly and completely enough for them to be able to get out at a profit. Thus it will be difficult to profit in a market where the minority of investors who pay attention to difficult-toprocess information react quickly, and the balance remain "asleep at the switch" and never react at all. Most of us accordingly probably would do well to assume that, rather than devoting time and effort to stock-picking, we should buy an index fund, or simply throw darts at the Wall Street Journal. ${ }^{113}$ But in light of the growing evidence that securities markets absorb some kinds of information only slowly and incompleteiy, we should also think twice before grounding academic research, regulatory policy, judicial case outcomes, or investment strategies, on a presumption of informational efficiency.

\section{EFFICIENT MARKETS AND INVESTOR IRRATIONALITY}

Parts II and III explored two important and relatively recent advances in finance theory that promise to shed great light on our understanding of how securities markets function: the development of asset pricing models that acknowledge heterogeneous investor expectations, and investigations of how limits to arbitrage can impede the rapid flow of information into market prices. At this point, a significant literature exists on each of these subjects, and there is every reason to expect each literature to continue to expand in the future. Yet, for sheer numbers of recent papers, there are few developments in finance, however intriguing or useful, that can rival a third intellectual challenge to traditional efficient market theory that has emerged in recent years. This challenge, of

110. If mutual funds are outperforming the market even slightly, someone else must be underperforming.

111. Coval et al., supra note 106 , at 18.

112. Id. at 18. For a similar finding of superior performance among a subset of investment newsletter analysts, see Vincent Pascual Pons-Sanz \& AloK Kuman, Behavior and PERFormanCe of InVESTMENT NEWSLETTERS ANALYSTS (2002), available at http://ssm.com/abstract=364000 (last visited Aug. 20, 2003) (reporting results of study finding that while investment newsletters do not exhibit superior performance at the aggregate level, "there are more individual newsletters that beat a buy and hold strategy on a risk-adjusted basis than can be expected by pure chance").

113. Over a period of fourteen years, the Wall Street Journal ran a contest in which more than 200 investment professionals pitted their investment skills against the results of a portfolio assembled by throwing darts at the Journal's stock tables. At the end of 142 contests to see which portfolio did best over six-month periods - the pros' or the darts'-the pros won by earning an average $10.2 \%$ investment gain per six month period, while the darts managed only $3.5 \%$ average gain. See Georgette Jasen, Putting Away the Darts After 14 Years: The Wall Street Journal's Dartboard Ends Its Run, WALL ST. J., Apr. 18, 2002, at C1. Although these results suggest that at least some people can indeed beat the market, I am unaware of any attempt to test their statistical significance. 
course, is the rise of so-called "behavioral finance." 114

Conventional efficient market theory, like economic theory in general, subscribes to a model of human behavior that might be described as the homo economicus model. According to this model, human beings are rational actors with stable preferences who are concerned exclusively with promoting their own welfare. In lay terms, homo economicus is a cool, calculating, level-headed actor who is never mislead by emotion and who never makes foolish mistakes.

Real people, of course, are not always rational. Sometimes we are mislead by our emotions, and sometimes we make foolish mistakes. The fundamental insight of behavioral finance is that human emotion and error can influence investment choices just as they influence choices to play lotteries or wear seatbelts. The trick, of course, is to figure out in advance just how this influence operates. To do this, behavioral finance theorists rely on the psychological literature, and especially on empirical studies of human behavior in experimental games, to identify predictable forms of "cognitive bias" that lead people consistently to make mistakes. They then examine whether these systematic biases can help explain or predict empirically-observed market anomalies that cannot be explained or predicted by rational-actor-based traditional finance.

It is difficult to overstate just how rapidly the behavioral finance literature has grown over the past decade. Over one hundred papers 115 and a number of books ${ }^{116}$ have been produced on the topic, which has also inspired specialty journals. ${ }^{117}$ Indeed, the number of behavioral finance papers being produced now rivals scholarly production in traditional finance. ${ }^{118}$

At the same time, many of the behavioral finance studies that have captured public attention are not the sort that would convince a skeptic that the field necessarily has much to offer in terms of developing our structural understanding of securities markets. For example, one recent study reports that stock prices are significantly influenced by the lunar cycle, ${ }^{119}$ while another concludes that seasonal affective disorder (SAD) leads stock returns to rise and fall with the seasonal lengthening and shortening of daylight hours. ${ }^{120}$ A third "behavioral finance" theory that has been discussed in the national

114. See, e.g., sources cited infra notes 115-117.

115. For useful surveys of the literature, see BARBERIS \& THALER, supra note 23; David Hirshleifer, Investor Psychology and Asset Pricing, 56 J. FIN. 1533 (2001). The rapid growth of the field is demonstrated by the results of a July 17, 2003 search of the Social Sciences Research Network database of social sciences abstracts, which found over 100 abstracts posted that included the phrase "behavioral finance." See SSRN.com (last visited Jul. 17, 2003). In contrast, a similar search found only 74 abstracts that employed the phrase "efficient markets." Id.

116. See, e.g., Hersh Shefrin, Beyond Greed and FEAR: Understanding Behavioral Finance AND the Psychology of Investing (2002); Robert J. Shiller, Irrational Exuberance (2000); Andrei SHLEIFER, INEFFICIENT MARKETS: AN INTRODUCTION TO BEHAVIORAL FINANCE (2000).

117. Examples include the newly-created Journal of Psychology and Financial Markets, and the SSRN's abstract service on "Behavioral and Experimental Finance."

118. See, e.g., supra note 115 .

119. See Ilia D. Dichev \& Troy D. Janes, Lunar CyCle EfFects In Stock Returns (2002), available at http://papers.ssm.com/abstract=281665 (last visited Aug. 20, 2003) (finding stock prices influenced by lunar cycle).

120. See MARK JaCk Kamstra et AL., WinTER Blues: A SAD Stock MARKET CyCle (2002), available at http://papers.ssrn.com/abstract=208622 (last visited Aug. 20, 2003) (finding stock prices influencd by seasonal changes in length of day) 
media-if not in a peer-edited journal-explains the late-1990s stock market bubble as a consequence of the increased use of antidepressants such as Prozac and Zoloft, with an attendant collective surge in investor optimism. ${ }^{121}$ (Sadly, this entertaining theory suffers from a number of flaws, most obviously its inability to explain the Crash of 2000 absent evidence the investing public suddenly and collectively "went off its meds.").

These sorts of studies have raised the profile of behavioral finance in the popular media. Unfortunately, they have also contributed to a perception among many theorists that behavioral finance is more suitable for dinner party conversation than for serious research. This perception has been reinforced by the rather large number of cognitive biases that have been argued to influence securities prices, some of them quirky, some of them short-lived, and some of them apparently contradictory. ${ }^{122}$ The net result has been the widespread impression that while behavioral finance sometimes may be useful to arbitrageurs, it has little to offer theorists other than a prediction that securities prices sometimes depart from informed estimates of value in arbitrary and capricious ways.

This impression is unjustified. More careful review of the behavioral finance literature quickly reveals that, in addition to offering insights into the effects of seasonal and lunar cycles, behavioral finance can also help explain market phenomena that are far more enduring and consequential. As an example, consider how behavioral finance may shed light on one of the most prominent puzzles in finance: the equity premium puzzle. ${ }^{123}$

The equity premium puzzle derives its name from the observation that the average historical return on the stock market has been much greater, relative to the average riskfree rate of return, than can be easily explained by a stock portfolio's somewhat higher level of market risk. Between 1926 and 1997, for example, relatively risk-free Treasury bills gave investors an average inflation-adjusted annual return of less than $1 \%$, while S\&P 500 stocks produced an average inflation-adjusted annual rate of return of nearly $10 \% .{ }^{124}$ It is difficult to explain this large gap without assuming that investors are not only risk-averse, but pathologically so.

Behavioral finance offers a solution to the equity premium puzzle by suggesting that it may be due in large part to a psychological phenomenon sometimes called "loss aversion"- an odd human tendency to neurotically dislike decreases in wealth, so much so that otherwise risk-averse actors will accept additional risk in order to gain a chance at avoiding such losses. For example, the same risk-averse person who would prefer a $\$ 100$ "sure thing" rather than gamble on a $50 \%$ chance at $\$ 200$, would also prefer, in a riskloving fashion, to take a $50 \%$ gamble of losing $\$ 200$ over a certainty of losing only $\$ 100$. According to this hypothesis, people demand a very large premium to hold stocks

121. See Richard Teitelbaum, Investing Diary: A Psychiatric Theory on Irrational Exuberance, N.Y. TimEs, Mar. 5, 2000, at C7 (offering "prozac effect" as explanation for the market upswing).

122. See Hirshleifer, supra note 115, at 1539 (noting that "[e]conomists have traditionally been skeptical of the varied array of seemingly arbitrary biases offered by experimental psychology").

123. See R. Mehra \& E. Prescott, The Equity Premium: A Puzzle, 15 J. Monetary Econ. 145 (1985); see also Faith Guvenen, A Parsimonious Macroeconomic MOdel for Asset Pricing: Habit Formation or Cross-Sectional Heterogeneity?, Univ. of Rochester Working Paper, at 2 (2002), available at $\mathrm{http} / \mathrm{ssrn} / \mathrm{com} / \mathrm{abstract}=361120$ (last visited Aug. 20, 2003) ("No other puzzle in the last two decades has probably generated as much interest and subsequent research as the equity premium puzzle.").

124. BREALEY \& MYERS, supra note 15, at 156, Table 7.1 (reporting that between 1926 and 1997 Treasury bills had $0.7 \%$ real rate of return, while S\&P 500 stocks had $9.7 \%$ real rate of return). 
because, relative to a risk-free investment like Treasury bills, stocks carry a much higher probability that in any particular year, the investor's portfolio might decline rather than rise in value. ${ }^{125}$ This prospect of intermittent loss is so psychologically painful that investors tend to shun stocks. ${ }^{126}$ Thus loss aversion, combined with risk aversion, leads real investors to refuse to hold equity securities unless they receive a disproportionately large return by doing so.

Similarly, behavioral finance can shed further light on the phenomenon of speculative price bubbles. As discussed in Part II, heterogeneous-expectations asset pricing models offer at least a partial explanation for bubbles, by predicting that when short sales are limited, an exogenous increase in business uncertainty that increases the dispersion of investor opinions is likely to raise marginal market prices even when average investor opinion is unchanged. ${ }^{127}$ Conversely, resolution of uncertainty that promotes greater investor agreement is likely to bring prices back down to their prior levels, even though average opinion again is unchanged. Thus heterogeneous expectations-based finance predicts that sudden and "inexplicable" price bubbles are most likely to be seen in the share prices of firms and industries confronted with a sudden increase in business uncertainty.

This explanation, while logical, nevertheless seems insufficient to explain what might be called "extreme" bubble phenomena. The late 1990s tech-stock bubble might be one example of such an extreme bubble; another can be found in the famed Tulip Frenzy of 1637 , during which the price of common tulip bulbs rose twenty-fold over a matter of months before suddenly sinking back down to prior levels. ${ }^{28}$ Put differently, heterogeneous-expectations asset pricing models can perhaps explain how a modest price bubble gets started. But how can we explain runaway bubbles where prices reach ridiculous heights?

Again, behavioral finance offers an answer. Psychologists' studies find that people suffer from a form of systematic cognitive bias that has been described as the "availability effect,"129 the "representativeness heuristic,"130 "adaptive expectations,"131 or, more simply, "trust." 132 Whatever label one chooses to apply, this bias is familiar to

125. See Shlomo Benartzi \& Richard H. Thaler, Myopic Loss Aversion and the Equity Premium Puzzle, 110 Q. J. ECON. 73 (1995) (explaining stocks outperformance over bonds based on behavioral concepts of loss aversion); see also Nicholas Barberis et al., Prospect Theory and Asset Prices, 116 Q. J. EcoN. 1 (2001) (incorporating "loss-aversion" into asset valuation framework with risk aversion as a function of investment performance).

126. It also leads to an empirically-documented investor reluctance to sell stocks that have declined in value in order to avoid loss realization, combined with a tendency to quickly sell stocks that have risen in value in order to realize the gain and make it a "sure thing." See BARBERIS \& THALER, supra note 23, at 50-52 (citing numerous findings of this "disposition effect" in the markets for stocks and other assets); see, e.g., Terrance Odean, Are Investors Reluctant to Realize Their Losses?, 53 J. Fin. 1775 (1998) (finding disposition effect).

127. See supra text accompanying notes 43-49 (discussing bubbles).

128. See Garber, supra note 6 , at 556 (concluding that price of common tulips experienced a bubble in 1637 that could not be explained by economic fundamentals).

129. See Hirshleifer, supra note 115, at 1542 (2001)

130. See Nicholas Barberis, Andrei Schleifer, \& Robert Vishny, A Model of Investor Sentiment, 49 J. FIN. ECON 307, 315-16 (1998).

131. See SHILLER, supra note 116 , at $60-61$.

132. See Lynn A. Stout, The Investor Confidence Game, 68 BrooKLYN L. REv. 407, 416 (2002) (identifying investors who look to past performance and trust that the behavior will continue in the future). 
anyone who has indulged in even the most casual observation of human behavior: people tend to extrapolate too readily from observed past events. In lay terms, they see trends when trends are not always there. Thus, if stock prices have risen in the recent past, investors may conclude, without any other evidence, that there is something going on that will cause prices to continue to rise in the future. Conversely, if prices have fallen for some period, investors expect them to continue to fall-again, even in the absence of evidence that would support this prediction.

This tendency to extrapolate helps to reconcile two well-established empirical findings that that seem, on first inspection, inconsistent with each other: the finding that stock prices tend to underreact (respond slowly and incompletely) to information that represents a departure from past patterns, and the finding that long-term changes in returns tend to be followed by reversals, suggesting that investors are overreacting to perceived trends in long-term returns. ${ }^{133}$ The apparent contradiction between these two findings has been used by Eugene Fama, a pioneer of traditional efficient market theory, to criticize the usefulness of behavioral finance on the theory that it fails to explain why "the same investors under-react to some types of events and over-react to others." 134 If people tend to extrapolate too readily from past events, however, it only makes sense that the same investors will underreact to earnings surprises, while also overreacting to more long-term shifts in earnings patterns that seem to evidence a trend. ${ }^{135}$

This possibility, when combined with the lessons of the HEAPM explored in Part I, ${ }^{136}$ suggests an intriguing joint explanation for such extreme bubble events as the tech stock bubble of the late 1990s. In brief, the development of new information technologies both modestly increased many corporations' profit margins and, more dramatically, introduced new uncertainty that greatly increased the dispersion of investors' opinions about likely future profits. The result was a significant rise in market prices, especially for information technology companies and for companies whose stocks were difficult to sell short. This price rise persisted for a sufficiently long period that investors began to perceive a trend - that is, they expected, without any more evidence, that the price rise would continue. As a result of this extrapolation, investors revised their subjective estimates of stock value upwards, leading to a further increase in price. This price increase only seemed to confirm the trend, leading to another upward revision in subjective valuations, leading to a further increase in prices, leading to another revision, and so forth, in a self-reinforcing process that eventually produced prices that experts widely viewed as unsustainable. ${ }^{137}$

At this point, the bubble was ripe for bursting, and burst it did. As the future became less murky and uncertainty resolved, prices became stable and then declined modestly. This lead to the perception of a new downward trend, which lead investors to revise their

133. See Eugene F. Fama, Market Efficiency, Long-Term Returns, and Behavioral Finance, 33 J. FIN. ECON. 3, 6-7 (1998) (describing overreaction and under-reaction evidence); supra text accompanying note 88 (describing findings of "post earnings announcement drift").

134. Fama, supra note 133 , at 4 .

135. Id. at 4, 8-9 (conceding that behavioral models that rely on "trending" can reconcile under- and overreaction, while critiquing these models on other grounds)

136. See supra text accompanying notes 38-66.

137. See SHILLER, supra note 116, at 63 (describing April 1999 poll in which $72 \%$ of professional money managers opined that the stock market was in a speculative bubble). 
subjective estimates of value downwards, depressing prices further, confirming the trend, and so on.

The end result is that if we combine two strands of the new finance-heterogeneous expectations asset pricing models and behavioral finance-we find a plausible explanation for an otherwise difficult-to-explain market event. Of course, speculative bubbles and the equity premium are only two of the many market phenomena that may usefully be reexamined in the light of behavioral finance. As these examples illustrate, however, behavioral finance offers considerable hope for making sense of what seems, under efficient market theory, to be nonsensical.

This is not an easy pill for those who have built their careers on the homo economicus model to swallow. Not surprisingly, many traditional theorists have responded to the rise of behavioral finance with a variety of criticisms. ${ }^{138}$ The discussion below considers two of the most common: that behavioral finance does not permit us to make useful predictions; and that irrational traders cannot be expected to influence market prices because they are likely to be quickly driven from the market by more rational traders.

Focusing on the first criticism, it has been suggested that behavioral finance has little value for theorists because, while it allows us to devise ad hoc and ex post explanations for market phenomena, it does not allow us to make predictions for the future. For example, it has been argued that, because behavioral finance theorists have identified a multitude of cognitive biases that can be expected to affect investor decisionmaking in different and often contradictory ways, it is therefore impossible to use behavioral finance to predict anything other than that prices will depart randomly and unpredictably from best estimates of value in light of available information. ${ }^{139}$

It is worth noting that this prediction-the prediction that market prices are not, in fact, either informationally or fundamental value efficient-is itself extremely valuable, as it reveals the risks of relying on corporate governance rules, executive compensation contracts, or event studies that presume market efficiency. It is also worth noting, however, that behavioral finance permits more testable predictions than many traditional theorists admit. Consider, for example, what behavioral finance may teach us about speculative bubbles. Although the HEAPM/behavioral approach does not allow us to predict with certainty exactly when and where extreme bubbles will occur, it does allow us to identify the types of situations where such bubbles are likely to occur-in particular, in markets where short selling is difficult and where market participants face an exogenous increase in uncertainty, and an increase in prices persists long enough to suggest to investors that they are witnessing a trend. ${ }^{140}$

Moreover, before we reject behavioral finance on the ground that it does not always allow precise predictions, we should consider the alternative-continuing to rely

138. See, e.g., BREALEY \& MYERS, supra note 15 , at 365 (critiquing behavioral finance on the theory that it cannot explain both over- and underreaction to new information); MALKIEL, supra note 15, at 241-42, 271-74 (arguing that efficient market theory may explain 1987 market crash and critiquing behavioral approach).

139. See, e.g., Fama, supra note 133, at 284 (employing this critique of behavioral finance).

140. In fact, these conditions applied in the cases of several famous historical bubbles. See, e.g., Garber, supra note 6, 543 n.22 (discussing how tulip bubble was precipitated by a French fashion of wearing tulips which increased demand and prices); JOHN KENNETH GALBRAITH, THE GREAT CRASH: 1929, 3-9 (1954) (discussing Florida land bubble of 1920s). 
exclusively on traditional finance even when its precise predictions are not borne out empirically. This approach elevates form over function in a manner that is hard to justify. To paraphrase uber-investor Warren Buffett, when it comes to understanding securities markets, it makes more sense to employ a model that allows us to make predictions that are messily and approximately right, than to hew to a model whose predictions are neatly and precisely wrong. ${ }^{141}$

Thus, we turn to the second common counterargument that has been raised against behavioral finance. This is the argument (dating back at least to Milton Friedman's writings in the 1950s) that irrational investors are unlikely to have much of an influence in a well-developed securities market because such investors will suffer systematic trading losses at the hands of more rational traders that drive them from the market. ${ }^{142}$ Gilson and Kraakman offer a version of this classic argument when they suggest that "market discipline in the form of heavy trading losses will restrain idiosyncratic [irrational] traders and may even eliminate them through a "Darwinian" process of natural selection."143

On close inspection, this Darwinian argument suffers from several flaws that seriously undermine its persuasiveness. Some of these flaws were explored in a series of influential articles published in the 1980s and early 1990s that proposed that securities prices were subject to "noise" (investor irrationality). This "noise trader" literature, which originated in an influential article by Nobel prize winner Fischer Black, ${ }^{144}$ pointed out that there was reason to believe that rational traders could not always expect to earn profits at the expense of irrational noise traders. Some papers argued, for example, that noise traders could persist in the market because their very presence increased the risks and costs associated with rational arbitrage against them. ${ }^{145}$ (This argument parallels some of the arguments about the limited power of arbitrage cataloged in Part II, including the argument that "a bargain that stays a bargain is no bargain.") 146 Others suggested that noise traders might be less risk-averse than rational traders. If so, noise traders might be able to survive by holding riskier portfolios that offered correspondingly greater returns, returns which helped to make up for noise traders' trading losses. 147

Such arguments may have merit. ${ }^{148}$ Nevertheless, there is a far more elegant and

141. See The Essays of Warren Buffett, Compiled by Larry Cunningham, 19 CARDOzo L. REV. 1, 71 (1997) ("It is better to be approximately right than precisely wrong.").

142. Milton Friedman, The Case for Flexible Exchange Rates, in EsSays in Positive Economics (1953).

143. Gilson \& Kraakman, supra note 3, at 583; see also Hirshleifer, supra note 115, at 1536 (noting the "traditiona! argument ... that wealth flows from foolish to wise investors").

144. Fischer Black, Noise, 41 J. FIN. 529 (1986). See also J. Bradford DeLong, Andrei Shleifer, Lawrence H. Summers, \& Robert J. Waldmann, Noise Trader Risk in Financial Markets, 98 J. PoL. ECON. 703 (1990) [hereinafter Noise Trader Risk]); J. Bradford DeLong, Andrei Shleifer, Lawrence H. Summers, \& Robert J. Waldmann, The Survival of Noise Traders in Financial Markets, 64 J. Bus. 1 (1991) [hereinafter Survival]; Andrei Shleifer \& Lawrence H. Summers, The Noise Trader Approach to Finance, 4 J. ECON. PERSP. 19 (1990) [hereinafter Noise Trader].

145. See, e.g., DeLong et al., Noise Trader Risk, supra note 144, at 705; Shleifer \& Summers, Noise Trader, supra note 144 , at 21.

146. See supra text accompanying notes $90-93$ (discussing limits to arbitrage).

147. See, e.g., DeLong et al., Noise Trader Risk, supra note 144, at 713; DeLong et al., Survival, supra note 144 , at 2 .

148. But see Hirshleifer, supra note 115, at 1538 ("despite the ingenious explanations for profitable 
persuasive argument that can be raised in support of the claim that irrational noise traders can survive quite nicely as a powerful force in securities markets. ${ }^{149}$ This argument does not rely on strong limits to arbitrage. Nor does it require that noise traders make money relative to rational traders. Instead, it relies on demographics.

The demographic argument for the persistence of irrational traders starts out by pointing out that there is no reason to believe that financial survival in a trading market is closely, or positively, correlated with biological survival. The "Darwinian" argument implicitly assumes either that market participants are immortal, or that financial success translates into reproductive success. In reality, of course, neither assumption is accurate. Securities markets are populated by mortals who are born, become employed, acquire assets, invest those assets, retire, disinvest, and die. The market does not die with them, however, because even as one investment cohort exits the market, another appears ready to invest. Recognizing this reality allows us to recognize that there is no fundamental inconsistency between the claim that rational traders make money at irrational traders' expense, and the claim that irrational trading can persist in markets.

Put differently, P.T. Barnum offers a rejoinder to Darwin. As long as there's a fool born every minute, fools can be expected to populate even trading markets where only the financially fittest survive. Thus, it is quite possible that irrational investors who try their hands at trading, and lose money, eventually exit the market. It is also quite possible, however, that because of the volatility and uncertainty associated with securities markets, it may take months-even years - for an irrational investor to figure out that his trading losses are due to his own foolishness, rather than to simple bad luck. Meanwhile, another irrational investor has appeared to take his place. The end result is that irrational investors' subjective opinions of value may have a continuing and significant influence on stock prices. ${ }^{150}$

\section{CONCLUSION}

With the publication of Eugene Fama's famous review article in 1970, the idea of an efficient securities market achieved the status of stylized fact among economists and finance theorists. ${ }^{151}$ In the tradition of legal scholarship-which often adopts the intellectual fashions of other fields long after they have reached their zenith in their home discipline-it took a decade for law professors to jump aboard the train in significant number. ${ }^{152}$ It is only a slight exaggeration to suggest that when they jumped, they

\footnotetext{
foolishness, it is quite plausible that, in fact, fools and their money are soon parted.").

149. See Stout, Casinos, supra note 23, at 635-40 (developing demographic argument).

150. See supra text accompanying notes 38-66 (discussing HEAPM); see also John Haltiwanger \& Michael Waldman, Rational Expectations and the Limits of Rationality: An Analysis of Heterogeneity, 75 AM. ECON. REV. 326 (1985) (discussing how opinions of "naïve" traders who do not have rational expectations can influence prices); see also sources cited supra notes 145-150 (discussing how "noise traders" can effect prices).

151. See Fama, supra note 20; SHLEIFER, supra note 116, at 9 ("As matters stood by the end of the 1970s, the EMH was indeed one of the great triumphs of twentieth-century economics. Standard economic theoryparticularly the theory of arbitrage-predicted that financial markets were efficient. Mountains of empirical evidence ... almost universally confirmed the predictions of the theory ....").

152. In the 1970s it was a rarity for a legal scholar to make use of the ECMH. For some pioneering early examples, see, for example, Harvey Bines, Modern Portfolio Theory and Investment Management Law: Refinement of Legal Doctrine, 76 ColuM. L. REv. 721 (1976); Daniel Fischel, Efficient Capital Market Theory.
} 
jumped with zeal. The 1980s saw a parade of law review articles applauding the markets' efficiency. ${ }^{153}$ Now, like a speculative intellectual bubble, law scholars' enthusiasm for efficient markets theory seems to have burst. By the 1990s, instead of publishing arguments for market efficiency, law reviews seemed to prefer to publish articles announcing the ECMH's demise. ${ }^{154}$

This pattern reflects more than academic trend chasing. During the 1970 s and early 1980 s, the ECMH seemed to enjoy solid empirical support. It is only in the years since that we have seen the steady accretion of empirical evidence against efficiency, including (but not limited to) evidence of pricing anomalies, demand inelasticity, excessive volatility, delayed information response, and consistently superior traders. Similarly, much of the legal literature arguing for or presuming market efficiency was written before collective faith was undermined by the Crash of 1987 and, more recently, the tech stock bubble of the late 1990's. It might be fair to suggest that it is only now, in the light of three decades of accumulated evidence and experience, that it would become apparent to a disinterested observer that the efficient market paradigm is failing.

But it does seem to be failing. This is not to say that market prices do not respond quickly to certain kinds of information, or that prices are utterly divorced from reasonable estimates of value. But the evidence at this point does not support the close correlation between price and value predicted by orthodox efficient markets theory. To use the words of Fischer Black, "we might define an efficient market as one in which price is within a factor of 2 of value, i.e., the price is more than half of value and less than twice value."155 The suggestion that stock prices can be assumed to be no more than twice and no less than half their actual worth does not inspire great confidence in the predictive value of efficient market theory.

Yet, if efficient market theory is losing ground, what can replace it? This Article argues that skepticism about the validity of the ECMH should not lead to skepticism about our ability to understand and predict market behavior. Indeed, the framework for a new understanding may already be in place. In particular, three strands of work in contemporary finance economics - the expanding literature on heterogeneous

the Market for Corporate Control, and the Regulation of Cash Tender Offers, 57 TEX. L. REV. 1 (1978); and John H. Langbein \& Richard A. Posner, Market Finds and Trust Investment Law, 1976 AM. B. FouND. RES. J. 1 (1976).

153. See, e.g., sources cited in Gilson \& Kraakman, supra note 3, at n.1, 2; and Stout, Unimportance, supra note 5 , at 5 .

154. Perhaps the earliest legal piece questioning the ECMH-predating even the 1987 market crash-is William K.S. Wang, Some Arguments That The Stock Market is Not Efficient, 19 U.C. DAVIS L. REV. 341 (1986) (questioning "the premise that the stock market efficiently prices securities"). By the 1990s, the trickle of legal articles questioning the market's efficiency had become a flood. See, e.g., Lawrence A. Cunningham, From Random Walks to Chaotic Crashes: The Linear Genealogy of the Efficient Capital Market Hypothesis, 62 GEO. WASH. L. REV. 546 (1994) (analyzing the strengths and weaknesses of the ECMH throughout its development); Donald C. Langevoort, Theories, Assumptions, and Securities Regulation: Market Efficiency Revisited, 140 U. PA. L. REV. 851 (1992) (providing overview of market efficiency theories and associated assumptions); James Lindgren, Telling Fortunes: Challenging the Efficient Markets Hypothesis by Prediction, 1 S. CAL. INTERDISC. L. J. 7 (1992) (describing model to test stock market efficiency); Louis Lowenstein, Efficient Market Theory: Let the Punishment Fit the Crime, 51 WASH. \& LEE L. REV. 925 (1994) (attributing efficient market theory to the market fallout in the 1980s); Stout, Efficient Market, supra note 37; Stout, Takeover Premiums, supra note 17.

155. Black, supra note 144, at 533. 
expectations asset pricing models; scholarly work on the limits of arbitrage and the delayed incorporation of new information into prices; and the burgeoning literature on behavioral finance-show signs of great promise as new ways of thinking about markets.

Taken separately, each of these three areas of work can explain market puzzles that have proven intractable under orthodox efficient market theory. Taken together, they offer the intellectual framework for a new theory that permits numerous testable predictions. Examples of such testable predictions include the predictions that, other things being equal: (1) issuing more shares decreases prices while share repurchases raise prices; ${ }^{156}(2)$ short sales restrictions raise price while developments that make shorting easier decrease prices; ${ }^{157}$ (3) increased uncertainty raises prices when the supply of outstanding shares is limited; 158 (4) prices underreact to information that is made available to the public in a form that is difficult to access or understand; ${ }^{159}$ (5) limited opportunities for profitable arbitrage exist and can be exploited by a minority of traders; ${ }^{160}(6)$ prices underreact to information "surprises" but overreact to information about long-run past performance; ${ }^{161}$ (7) equities should offer significant excess returns relative to risk-free investments even after adjusting for nondiversifiable risk, ${ }^{162}$ and last but not least, (8) prices do not necessarily bear any close relationship to the best possible estimates, in light of the available information, of securities' expected risks and returns.

As this partial listing indicates, the new finance literature paints a picture of capital markets that is far more nuanced and complex than the simple portrait sketched by what is still sometimes called "modern finance" (recently described by a former Wall Street rocket scientist as "finance theory with vacuum tubes"). ${ }^{163}$ What's more, this detailed portrait bears a much closer resemblance to the way actual market participantscorporate executives, investment bankers, stock analysts, and investment professionalstend to think the market behaves. The possibility of convergence between the views of academics and those of practitioners should, perhaps, be viewed as cause for optimism. It would be worrisome if so many apparently intelligent people (for clarity it should be noted, with due deference to academics, that it is the practitioners being referred to here) could be so wrong for so long in their beliefs about phenomena they experience first hand and have great personal incentive to observe accurately.

Similar optimism permits the suggestion that a new paradigm in finance is not only urgently needed, it is well on its way to emerging. There is, of course, room for pessimism in this regard. Many of the ideas that provide the foundations for the new finance have been around for nearly as long as the ECMH itself. John Miller, for example, published his "famous" paper on heterogeneous expectations asset pricing in $1977 .{ }^{164}$ Yet, a quarter of a century later, many basic texts in finance economics still

156. See supra text accompanying note 50 .

157. See supra text accompanying note 59 .

158. See supra text accompanying notes 43-48.

159. See supra text accompanying notes 80-102.

160. See supra text accompanying notes 103-112.

161. See supra text accompanying notes 129-135.

162. See supra text accompanying note 123.

163. Informal discussion with Peter Huang, Assistant Professor, University of Pennsylvania School of Law, Iowa City, lowa (Apr. 4, 2003).

164. See Miller, supra note 9. Similarly, Fischer Black published the renowned precursor to behavioral finance, Noise, in 1986. See Black, supra note 144. 
discuss in detail only the conventional ECMH and CAPM. ${ }^{165}$ If the alternatives are mentioned at all, it is only briefly, or in the footnotes. ${ }^{166}$

Why is the intellectual progress so slow? Thomas Kuhn likely offered part of the answer in his influential book, The Structure of Scientific Revolutions. ${ }^{167}$ As Kuhn observed, the individuals who pioneer a new theory are also often those who are most reluctant to revise it in the face of contradictory evidence. ${ }^{168}$ As a result, intellectual growth must often await the arrival of a new generation of scholars less committed to defending the validity of the dominant paradigm.

This may be only part of the story, however. The remainder can, perhaps, be found in the pages of Gilson and Kraakman's The Mechanisms of Market Efficiency. ${ }^{169}$ As Gilson and Kraakman explain, the degree of efficiency we observe in securities markets must ultimately depend on a number of variables, including the extent to which investors have rational and relatively homogeneous expectations and the ease with which information can flow into prices. Just as investors often disagree in their views of stocks' value, theoreticians often disagree in their views of the values of different models. Just as complex and technical information may move into prices relatively slowly, complex and nuanced theories may move into the academic culture more slowly than models that can be captured in a sound bite. Finally, just as investors may depart from rational expectations by overweighting evidence of long-term past performance, scholars may give undue weight to the validity of old judgments about the value of a model or theory. Thus, as Gilson and Kraakman observe, understanding how securities markets work gives us insight into other types of markets ${ }^{170}$ _including the market for ideas.

165. See, e.g., BREALEY \& MYERS, supra note 15, 195-203 (analyzing CAPM in detail); MALKIEL, supra note 15, at 220-39 (same). This is not to suggest that basic finance texts should omit the basic ECMH and CAPM; to the contrary, these are essential foundational ideas for much of the new finance.

166. See, e.g., BREALEY \& MYERS, supra note 15, at 205-06 (briefly discussing arbitrage pricing model); MALKIEL, supra note 15, at 234-236 (same)

167. KuHN, supra note 19.

168. Id. at 158-59. Compare Fama, Market Efficiency, supra note 133 (critiquing behavioral finance on a number of grounds) with Hirshliefer, supra note 115, at 1535 (demonstrating that these same objections, or slight modifications of them, can be applied to critique traditional finance).

169. Gilson \& Kraakman, supra note 3.

170. See id. at 643 ("the extent of informational efficiency is surely a central determinant of the pricing behavior and institutional underpinnings of all markets, and not merely of the securities markets."). 
